The Geneva Papers on Risk and Insurance, 19 (No. 73, October 1994), 433-471

\title{
Options for Extending the Working Period and Flexibilising the Transition to Retirement in the German Insurance Industry - the Current Situation and Assessment for the Future -*
}

\author{
by Winfried Schmähl and Jutta Gatter**
}

\section{Introduction}

\subsection{General remarks}

The impact of the ageing population in the Western industrialised nations has long been debated and discussed. Germany is now expected to encounter a shortage of labour from the year 2010 onwards ${ }^{1}$. This is bound up with a structural change within the labour market, with more and more older employees and fewer and fewer younger ones. ${ }^{2}$

The problems that are thus anticipated regarding the financing of the statutory pension insurance scheme have already led to reforms aimed at spreading the rising burden resulting from demographic developments among pensioners, contributors and government budgets. The Pension Reform Act, which was passed in 1989 before German unification, has been in force since 1.1.1992.

* This study was produced with the support of the Association Internationale pour l'Etude de L'Economie de l'Assurance (the Geneva Association) and forms part of an international research project on improved opportunities for employing elderly people in the interest of coping with problems of old-age assurance in times of demographic change.

** Zentrum für Sozialpolitik, Universität Bremen.

1 Prior to German unification, it was assumed that this situation could occur somewhat earlier. Increased immigration levels, in particular, are liable to postpone this development a little (see Schulz 1993, Grütz et al. 1993, Sommer 1992). A comparative analysis of model calculations can be found in the Interim Report of the Enquête Commission on Demographic Change, Chapter 3.

2 These structural impacts are more incisive than the global consequences of population changes. Klauder, for example $(1986,95)$, fears there will be negative effects on the economy's capacity for innovation, adaptation and output. 
One of the interesting features of this $\mathrm{Act}^{3}$ with respect to the question of opportunities for extending the working period is the introduction of the partial pension. The partial pension enables a gradual transition to retirement, also beyond the normal retirement age to date, namely 65. Introducing partial pensions is an attempt to achieve objectives that gerontologists, especially, had argued for, such as the avoidance of an abrupt transition to retirement, or the extension of the working period within the life course and reducing the duration of full pensions, thus leading to a lower financial burden caused by pension insurance.

In the short term, however, extending the working period in Germany is not an acceptable political solution, given the present level of more than 4 million persons registered as unemployed. On the contrary: for most employees, the transition to retirement occurs abruptly and as early as possible, regardless of whether they are employed in a declining or prospering sector of the economy. However, there is little empirical data on the extent to which income is earned alongside full pensions in Germany.

For years now, many companies and public service employers have been carrying out staff cuts they consider necessary in the form of early retirement schemes or using the socalled "59" regulation, according to which employees aged 57-58 can exit from the labour force. ${ }^{4}$ Over the last 20 years, the labour force participation rate among 55-65 year old people has fallen, as is clearly shown in Figure 1.

Through an implicit and explicit consensus between the state, employees and employers, early retirement has become a socially accepted means for combating unemployment and a "normal" phenomenon (see Kohli 1993, 187). ${ }^{5}$ It makes older workers a "resource for adjusting personnel structures" without regard to their productivity (see Rosenow 1992a, 151). However, it should not be forgotten that the majority of employees wishes to retire as early as possible (provided that income is sufficient). The existing opportunities for early exit from the labour force have had a decisive influence on expectations regarding the desirable age at which the (official) working period should be ended.

However, this "externalisation strategy" will come under pressure in the light of demographic ageing, because in future innovations will have to be implemented with existing staff to an increasing degree. ${ }^{6}$ Skilled, motivated personnel will be an essential resource in coping with intense international competition. Older employees could repre-

${ }^{3}$ For an overview, see Schmähl (1993).

4 Until 1990, the dismantling of jobs in eastern Germany in the transition to the market economy was largely carried out through early retirement, then with pre-retirement benefits enabling those aged at least 55 to bridge the period until statutory retirement benefit could be received. In the second quarter of $1991,508,000$ people in the new German states were awarded pre-retirement benefit. The peak level, 896,700, was reached in the first quarter of 1993 (see Deutsche Bundesbank 1993, 63). Since unification, the labour force participation rate of older people has fallen dramatically; see Rosenow 1992b or Kohli 1993, $201 \mathrm{f}$ on the situation in the former GDR.

${ }_{5}^{5}$ (Early) retirement has become established in former West Germany as a separate life phase. The statutory framework provides employees with a certain degree of scope regarding the timing and the type of retirement.

${ }^{6}$ Unless one relies on being able to continue in a situation of greater competition for young workers (and immigrants) with the most up-to-date training, or one transfers innovation and production to countries with a growing abundance of cheap and highly-qualified labour. This may be an attractive option at the microeconomic level, but is unfeasible for the economy as a whole. 
Figure 1:

Development of the labour force participation rate of men and women in Germany

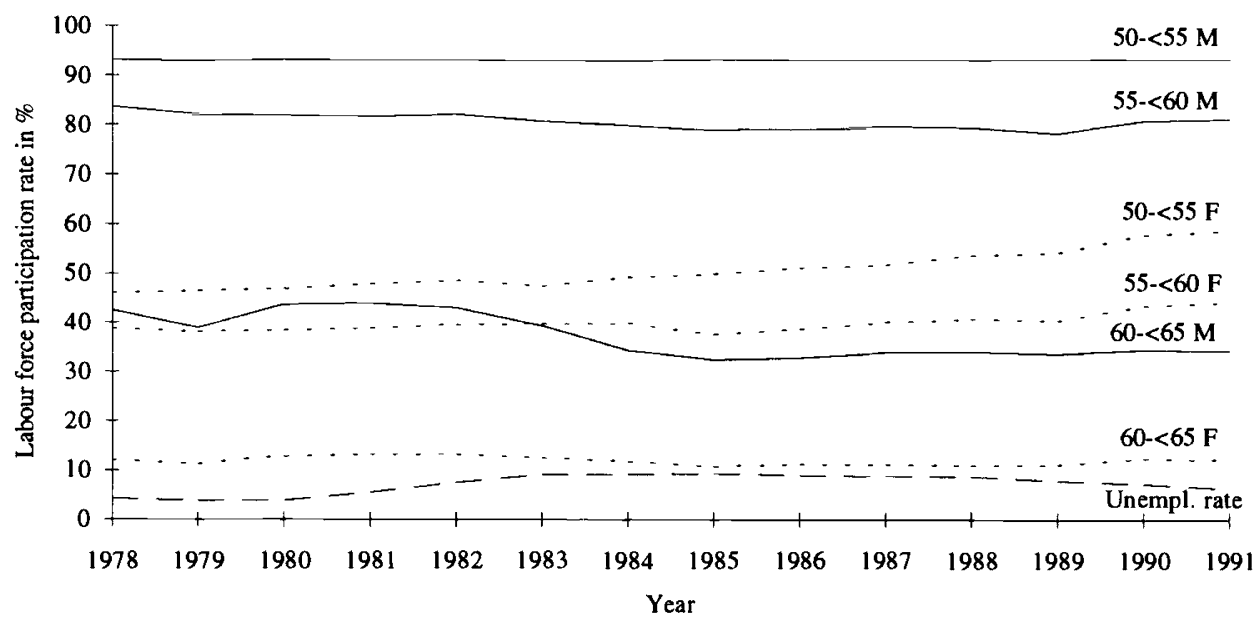

Source: Microzensus

sent an important resource in this connection, since assuring human resources in the right quality and quality is a key task of personnel management (see Nienhüser 1989, 13). However, there have been hardly any studies so far which have examined the influence of demographic changes on the labour force potential and the personnel structures of enterprises. According to Weber (1990), the impact of demographic changes has received greater attention in the field of product policy and marketing, and less in the personnel field. ${ }^{7}$ Personnel policies in most companies have been more reactive than preventive, whereby reactions have focused less on foreseeable population developments than on the symptoms caused by a lack of reaction (see Weber 1990,276). This leads to restricted scope, however, since only when the relevant problems are recognised well enough in advance can appropriate action be taken to shape the future.

\subsection{Objective of the study and methods chosen}

As already mentioned, the benefits of phased retirement have been corroborated by many academic studies. On the international level, the Geneva Association, especially, has dedicated considerable attention to a more flexible shaping of the working period and a gradual transition to retirement. Both theoretical ${ }^{8}$ and empirical studies ${ }^{9}$ have been funded

\footnotetext{
7 This is the approach that life assurance companies have been taking towards older citizens for some time now. However, life assurance policies are also being propagated to younger people as a form of security in the event that statutory retirement pensions are no longer assured.

8 See, in particular, Kruse/Steinjahn 1988.

${ }^{9}$ See, for example, Rajan/van Eupen 1990, Rajan/van Eupen 1991 and Reday-Mulvey 1991.
} 
under the general heading of "Potentials for the fourth pillar"10. This was also the context for the study presented here, which no longer deals with the theoretical foundation for the "fourth pillar strategy" in different countries, but examines in a further-reaching step whether and under what conditions such a strategy is implemented in enterprises. Only more recent developments are dealt with in our study, an aspect that is also reflected in the choice of focus.

An ageing population has two important implications for our study:

(1) Structural change will have to be coped with to an increasing extent using middleaged and elderly employees, a situation that companies can prepare for by instituting longterm personnel (development) planning. ${ }^{11}$

(2) An extended working period within the life cycle must be striven for in order to safeguard the development of pension finance. Employers and employees must change their thinking in this respect. By enacting the Pension Reform Act of 1992 the state has already changed the conditional framework and incentives to this end.

Our investigations thus pursue twin objectives. In the first field of investigation we ask, with the help of a pertinent study within one sector, to what extent companies have already recognised the demographic changes and the challenge these represent, and developed long-term personnel planning concepts to meet that challenge. ${ }^{12}$ One central area is therefore the shaping of internal labour markets. For example, companies could attempt:

- to keep older employees in employment for a longer period

- to keep women in the labour market after they have given birth to children or

- to make greater use of immigrant workers.

The latter option could prove difficult for the insurance sector, because a lack of linguistic skills can be a problem in a sector which demands a great deal of customer contact. Most insurance companies operate on their own domestic markets. There are only a few companies that operate internationally to any major extent, and for which foreign employees are therefore an interesting resource. ${ }^{13}$

Nevertheless, all 3 options demand different personnel policies from those which have predominated so far, namely long-term personnel planning that integrates life-long

${ }^{10}$ Cf. Giarini 1990.

${ }^{11}$ It should be pointed out here that changed personnel structures can have a critical impact on some areas of personnel management (see Nienhüser 1989, 14). According to Weber $(1990,275)$, an unbalanced age structure can lead to major problems. These include, in particular: qualification and training problems, blocks on innovation, narrower horizons for personnel development, and the problems that these trigger with respect to motivation, integration of new employees and recruitment. Investigating these issues is a subject for "organisational demography", and is not dealt with further in this context (see, for example, the work of Nienhüser or Pfeffer 1985).

${ }^{12}$ Recognising the interplay between demographic changes and the personnel field depends, according to Nienhüser $(1989,29 \mathrm{ff})$, above all on the education level of the relevant decision-makers. The more social scientific training, involvement with personnel issues they have, and the higher their qualifications, the more likely they are to perceive the changes and the challenges that these imply.

${ }^{13}$ It remains to be seen whether this assessment will have to be revised following liberalisation in the Single Market. 
training and a more flexible shaping of workplace and working hours. This is one key hypothesis. Only if these two factors are interlinked are investments in older employees a viable proposition for companies, because only then can returns on such investments be achieved. However, it is by all means possible that personnel policies as they have been pursued to date will offer a good basis for demographically oriented personnel policies, even if companies today do not yet perceive that they will be facing recruitment problems in a matter of years. Examples here include more flexible working hours (in terms of both chronology and chronometry), personnel development and further training, and integration of women into the labour force. Early retirement and the renewed employment of younger people in recent years can also be interpreted as long-term strategies. Firstly, replacing older employees by younger (and generally more qualified) ones produces productivity benefits in the short term as well; secondly, people who are used to learning can be expected to be more capable of learning when they are older than others. Another aspect is the high level of unemployment among those with basic vocational training. If young people are not integrated into working life as quickly as possible, there is a risk that they will lose both their ability to learn and their motivation to work before they finally obtain, after a period of years, the chance of a job. ${ }^{14}$

The second field of investigation relates to the implementation of the statutory partial pension scheme in enterprises. The question to be asked was, whether companies are already utilising the opportunity provided by state legislation to shape or even extend the working period for (individual) employees by means of a gradual, step-by-step transition to retirement, in order to gain useful knowledge and experience for later planning.

If the partial pension option is not being made use of to any significant extent, then the reasons for this must be ascertained. Is there a general rejection of phased retirement or extending the working period, are the specific arrangements at fault, or are we simply dealing with teething problems? Is the partial pension unattractive in the current labour market situation, or is the entire concept without incentives for the insurance industry in particular? Is the partial pension compatible with company pension schemes? Would this new instrument run counter to existing retirement policies within insurance companies?

Important for both fields of investigation is an assessment of the "acceptance theory" postulated by Drumm and Scholz (1983), according to which there are conditions for acceptance which must be met in order to successfully introduce an innovation into a company. The first, main, condition is that the problem be so pressing for the personnel planners that previous strategies are no longer considered adequate to solve it. ${ }^{15}$

This also corresponds with Nienhüser's hypothesis $(1989,31)$ that the perception of long-term problems can be obscured by acute problems (such as the current economic situation), due to the fact that the problem-solving capacity of every individual is limited and acute problems are classed as more urgent.

14 Early retirement policies can also be interpreted in organisational demography terms as prospective, since a high proportion of elderly workers can result in promotion barriers that render the company unattractive to younger employees.

15 This theory, which was originally developed for the acceptance or implementation of formal personnel planning methods, can be transferred, according to Drumm $(1983,37)$ to all forms of innovation. The most recent example providing empirical confirmation of the theory is the introduction of a new working time model at VW. Hartz (1994) provides a good desciption of the situation at VW. 
The insurance industry was selected for an examination of the issues mentioned above because, for a variety of reasons, it seems predestined to perform a "pioneering role". Firstly, the insurance industry belongs to the services sector, the potential of which has not yet been fully exploited. Secondly, the insurance industry was among the prospering sectors (during the period under review), employing an increasing number of workers, so that redundancy and early retirement problems could be assessed as less critical than in other sectors of the economy. Thirdly, the insurance industry employs personnel with above-average qualifications compared to the economy as a whole, and does not fall victim to "burn-out" as a result of hazardous work procedures. The employee groups concerned, so the thesis runs, are ones which could remain in employment for longer than is the case today if training and personnel development, and the shaping of tasks and working hours within the life course were done prospectively. As already mentioned, however, early retirement of as high a proportion of today's elderly employees, combined with the recruitment of many young and better qualified staff, could also be evidence of such prospective policies.

Structured interviews were conducted between May 1993 and March 1994 in seven insurance companies in Germany. The interviewees were mainly personnel directors or executives in the personnel department.

Despite the considerable reservations shown by insurance companies regarding the disclosure of internal information, we were able to survey a representative selection of companies. We succeeded in persuading smaller, medium-sized and large companies to participate, including direct insurers, reinsurers and one public-law insurance company. ${ }^{16}$

In addition to the qualitative interviews, a questionnaire was used to obtain data on personnel structure, as were company publications (management or personnel reports). However, not all the companies surveyed were willing to provide us with such data, so conclusions can only relate to general trends. This also meant that one original aim, namely to establish which causal links exist between personnel structure and the influence this has on corporate policies, could not, therefore, be attained.

Problems arise above all in relation to the focus on "partial pensions". The refusal to provide information was generally explained by lack of time, but also with the fact that any extension of the working period was not on the agenda in the current economic situation. This was also confirmed by those companies that actively participated - an indicator that personnel planning in many companies is heavily oriented towards the current labour market situation, evidence of a somewhat short-term perspective. A fundamental problem made itself felt here - companies almost always identify the partial pension with extension of the working period. But it can also be deployed as a means of reducing headcount if older employees work part time rather than full time and no replacement is recruited. While this was not the legislator's original intention when introducing the partial pension, it must be seen as genuine competition for the retirement pathways typically available to date. The fact that the companies have failed to realise this so far can perhaps be explained by deficits in information.

${ }^{16}$ Of all the companies invited to participate, one third actually did so - a high percentage for company-based surveys. 


\section{Legal regulations governing the transition to retirement}

In order to assess in-company options for shaping the transition to retirement it is necessary to know what other alternatives are available to the company and its employees regarding the transition from the employment to the retirement phase. It therefore makes sense to provide a brief overview of existing retirement options and the conditional framework and incentives defined for the future by the state. Conditions established by the state must obviously be accepted by employees and employers alike if they are to have any success. This applied for the former introduction of facilitated choice of earlier retirement, and is also required for the development aimed for - a genuine increase in the retirement age.

\subsection{Transition options prior to 1992}

The average age on exit from the labour force has fallen markedly in Germany over the last 20 years. The normal retirement age of 65 for men has become an upper limit for the awarding of pensions. Employees generally withdraw from working life at the earliest possible opportunity. Figure 2 shows the possible transition pathways.

Looking purely at the options available under the statutory pension insurance system, the following types of pension can be identified:

Formally speaking, disability pensions are not old-age pensions. However, because they denote a substantial proportion of all pensions and enable many employees with impaired health to make the final transition to retirement, it is included here as a transitional pathway. ${ }^{17}$ The possibilities for accessing a disability pension will have a determining influence on the success or failure of the rising "deduction-free" age limit in the pension insurance system from the year 2001 onwards. If the conditions for obtaining a disability pension remain unchanged, many employees could make use of this type of pension to ensure that the average "deduction-free" retirement age does not rise in relation to today's level. ${ }^{18}$

Old age pensions can be awarded on meeting various different conditions:

- on reaching 60 (severely disabled persons, women, the unemployed)

- on reaching 63 (men with many years of contributions) or

- on reaching 65 ("normal" retirement age).

The Early Retirement Act, which enabled 58-year-old workers to withdraw from the labour market and to bridge the gap until the earliest possible receipt of a pension with payments from the respective employer, also served during the 1984-1988 period as a means of alleviating labour market pressures. ${ }^{19}$ Early retirement benefit amounted to at

17 The risk of becoming vocationally or generally disabled before the age of 60 rises disproportionately from the age of 50 onwards, reaching a peak between 55 and 60 (see Hoffmann 1993, 314).

18 Cf. Rosenow 1993.

19 Retirement benefit for the unemployed competed strongly with early retirement, since it was the cheaper option for companies. When the Early Retirement Act came into force, employers were under tougher obligations to reimburse the Federal Labour Office for the unemployment benefit paid to older employees made redundant. 
Figure 2:

Options for the transition to retirement provided for under social insurance legislation

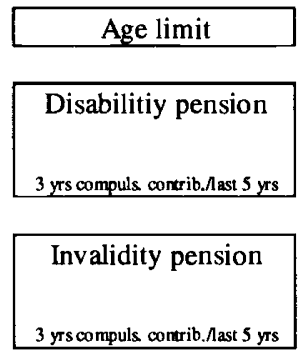

\begin{tabular}{|c|}
\hline " 59 " Regulation \\
52 wks unemploym $/$ ast $11 / 2$ yrs \\
8 yrs compuls. contrib. /ast $10 \mathrm{yrs}$ \\
\hline
\end{tabular}

Full pension at 60 for women

10 yrs compuls. contrib. from age 40

Full pension at 60 Disabil./nnvalid./severe disablement 35 yrs contribution

Full pension at 63

35 yes contribution

Full pension at 65

entitement to a retirement pension
fewer hours/less pay

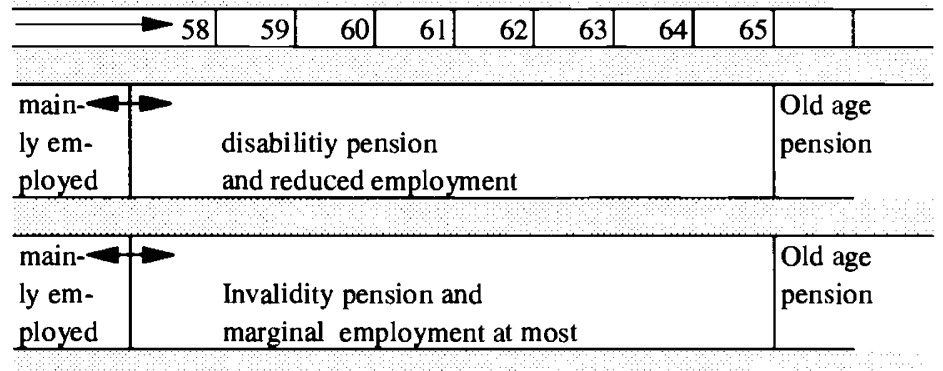

\begin{tabular}{l|l|l}
$\begin{array}{l}57 \overrightarrow{\mathrm{J}}+4 \mathrm{mo} \\
\text { mainly } \\
\text { employed }\end{array}$ & $\begin{array}{l}\text { unemploy- } \\
\text { ment benefit }\end{array}$ & Old age pension for unemployed persons \\
\hline
\end{tabular}

\begin{tabular}{l|l}
\hline mainly employed & Old age pension for women \\
\hline
\end{tabular}

\begin{tabular}{l|l}
\hline many years in employment & $\begin{array}{l}\text { Old age pension in the event } \\
\text { of reduced fitness to work }\end{array}$ \\
\hline
\end{tabular}

\begin{tabular}{l|l}
\hline many years in employment & $\begin{array}{l}\text { Old age pension } \\
\text { for persons insured } \\
\text { for a long period }\end{array}$ \\
\hline
\end{tabular}

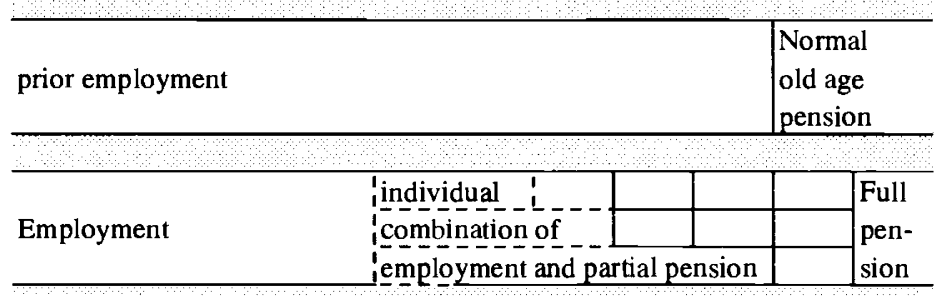

\section{Source: Viebrok 1993, 88}

least $65 \%$ of final gross income, but could also be set higher through collective bargaining agreements. ${ }^{20}$ If the vacant job was then filled again, the Federal Labour Office paid a subsidy amounting to $35 \%$ at most. An unusually high proportion of those employees who

${ }^{20}$ In most carss, benefit amounted to about $75 \%$ of final gross earnings; see Meinhardt/Zwiener $1988,44$. 
were entitled to take early retirement on the basis of collective bargaining agreements about $70 \%$ - actually did so. Nevertheless, this option was not taken advantage of to the extent hoped for, because the early retirement agreements which were concluded covered only about one third of all employees liable to compulsory social insurance contributions. In particular, early retirement was not introduced in the public service sector, i.e. the state enacted a law enabling early retirement but did not set a "good example" by making use of it. $^{21}$

The Early Retirement Act was replaced on 1.1.1989 by the Part-time Work in Old Age Act. ${ }^{22}$ This is interesting for our analysis, in that it was the first attempt to establish a phased retirement system at federal level. Employers who reached agreement on part-time work with an employee aged at least 58 could receive a subsidy from the Federal Labour Office if the following conditions were met:

- the employee had to reduce his weekly hours by half, and work at least 18 hours a week on average;

- the employer was obliged to supplement pay by at least $20 \%$;

- the employer also had to pay the difference in pension insurance contributions between the part-time pay and $90 \%$ of the previous pay level;

- the vacant job had to be filled with someone who was unemployed.

If these criteria were fulfilled, the Federal Labour Office also paid the remaining difference in pay and in pension insurance contribution. ${ }^{23}$ The prime objectives of this system related to the labour market. Financially, the law was not particularly attractive and failed to achieve success - an indicator for the dominance of the labour market and income effects (for employees) where retirement decisions are involved.

Before the Early Retirement Act came into force, as well as after its recission, collective bargaining agreements on early retirement were concluded in a number of sectors ${ }^{24}$, including the insurance industry. ${ }^{25}$

\subsection{The early retirement agreement in the insurance industry}

The early retirement agreement pertaining to the insurance industry has been in operation since 1.4.1992. ${ }^{26}$ It corresponds largely with the agreement that was in force while

21 See Schmähl/Conradi (1984) and Hoffmann/Kühlewind (1984) regarding the debate over the impact of the early retirement regulations on employment.

22 The operativeness of this law was restricted to the period between 1.1.1989 and 31.12.1992.

${ }^{23}$ Because employment was no longer full-time, lower pension insurance contributions had to be paid, which in turn reduced the level of pension entitlement. To increase the attractiveness of parttime work for older employees, pension contributions equivalent to those made before the part-time employment phase were paid.

${ }^{24} \mathrm{E}$.g. in the cigarette industry, the chemicals industry and the banking sector.

25 The incentive for companies to conclude early retirement agreements was higher when the Early Retirement Act was still in force, however, since part of the costs could be assumed by the Federal Labour Office, whereas the present situation is that the employer alone bears these costs.

${ }^{26}$ Even before the agreement came into effect, some insurance companies were offering early retirement to employees at the same conditions, but on the basis of individual contracts. 
the Early Retirement Act was still operative. The preamble to both agreements stresses that early retirement is aimed at alleviating labour market pressures and improving the job prospects of younger people. Preference was therefore to be given to the employment of young people with successful vocational training in the respective company when jobs became vacant following early retirement.

Employees aged 58 and above who have worked in the company for at least 10 years and who have at least 3 years to wait before reaching 65 or obtaining an old age pension from the statutory pension insurance scheme are entitled to take early retirement under the agreement. ${ }^{27}$

The employment relationship must be terminated in writing before early retirement can be taken. Early retirement benefit amounts to $75 \%$ of the gross pay received in the last month before early retirement commences, or $80 \%$ in the case of 20 years' service and more in the company. This early retirement benefit is also subjected to increases in line with the linear pay rises defined by the collective bargaining agreement. Benefits are not paid if the employee takes on employment or becomes self-employed during the early retirement phase and earns more than the lower limit for compulsory social insurance contributions. Entitlement to early retirement benefit is cancelled if such work is done on more than 150 days.

This option is taken advantage of under the current and the previous collective bargaining agreement by about $40 \%$ of those entitled to do so (figure provided by agv).

\subsection{New transition pathways provided for by the Pension Reform Act of 1992}

The 1992 Pension Reform Act also contains measures aimed at increasing employment among older workers. ${ }^{28}$

The relevant measures for our purposes include, in particular:

- The age limit from which a retirement pension can be awarded without deductions for early retirement will be increased step by step from 2001 onwards until it has reached the reference retirement age of 65 . In the case of early retirement, the pension awarded will be reduced by $0.3 \%$ per month. After the transition period, a retirement pension can only be awarded to people aged at least 62 . Those who remain in employment beyond 65 years of age and continue to pay social insurance contributions will receive a pension increase. Such increases are already granted today.

- The introduction of a partial pension enabling phased retirement. Since 1992, employees satisfying the conditions for a retirement pension can continue to work, within certain income limits, and still receive part of the pension they would otherwise be entitled to.

The partial pension can be $1 / 3,1 / 2$ or $2 / 3$ of the full pension. The earnings limit is dependent on the level of previous individual earnings and the type of partial pension. The principle applied is as follows: the lower the level of previous earnings and the higher the type of partial pension, the lower the earnings limit (and vice versa). This regulation is therefore based purely on income, and allows the partial pensioner to negotiate the number

${ }^{27}$ Between 1986 and 1988, workers had to apply for early retirement within 4 years at most of their first being able to receive an old age pension.

${ }^{28}$ See Schmähl 1992 for more detail. 
of hours he or she works. This arrangement is thus highly flexible, although it also involves high transactions costs. Collective agreements could therefore prove beneficial to both employees and employers.

For a "standard pensioner" (with 45 income points, e.g. a person who was employed for 45 years, receiving average pay) the gross income limit as a partial pensioner (comprising gross pay plus pension) is currently between 70 and $91 \%$ of the average gross income in the year before retirement; see Figure 3 below for an example.

Figure 3:

Example for calculating gross income under the partial pension scheme (West Germany, 1.1.94-30.6.94)

\begin{tabular}{|l|c|c|c|c|c|}
\hline \multicolumn{1}{|c|}{$\begin{array}{c}\text { Partial } \\
\text { pension }\end{array}$} & $\begin{array}{c}\text { Supplementary } \\
\text { income limit } \\
\text { (DM) }\end{array}$ & $\begin{array}{c}\text { \% of last } \\
\text { gross } \\
\text { earnings }\end{array}$ & $\begin{array}{c}\text { Pension } \\
\text { (DM) }\end{array}$ & $\begin{array}{c}\text { Total } \\
\text { (DM) }\end{array}$ & $\begin{array}{c}\% \text { of last } \\
\text { gross } \\
\text { earnings }\end{array}$ \\
\hline One third & 3114.30 & 75 & 667.35 & 3781.65 & 91 \\
Half & 2335.73 & 56 & 1001.03 & 3336.75 & 81 \\
Two thirds & 1557.15 & 38 & 1334.70 & 2891.85 & 70 \\
Full pension & 560.00 & 13 & 2002.05 & 2562.05 & 62 \\
\hline
\end{tabular}

Source: Own calculations, adapted from Viebrok 1993, 98

Depending on the individual's employment history and income from gainful employment (and hence the level of pension entitlement), total income from pension and gainful employment may be considered too low in relation to the average gross pay during the last year of employment, with the result that the partial pension regulation could lose any attractiveness it may otherwise have. Whether that is the case or not depends on many other factors: on how the individual is taxed (which also depends on marital status), on alterations in other transfer payments, but also on whether payments can also be made from company pension schemes.

Figure 4:

Example for calculating the gross income of an employee in the insurance industry taking early retirement in 1994

\begin{tabular}{|c|c|c|c|c|}
\hline $\begin{array}{c}\text { Early retirement } \\
\text { benefit }\end{array}$ & $\begin{array}{c}\text { \% of last } \\
\text { gross earnings }\end{array}$ & $\begin{array}{c}\text { Supplementary } \\
\text { income limit }\end{array}$ & $\begin{array}{c}\text { Total } \\
\text { (DM) }\end{array}$ & $\begin{array}{c}\text { \% of last } \\
\text { gross earnings }\end{array}$ \\
\hline 3104.25 & 75 & 560 & 3664.25 & 88.5 \\
3311.20 & $80^{29}$ & 560 & 3871.20 & 93.5 \\
\hline
\end{tabular}

Source: Own calculations on the basis of the average income level applicable for 1993 (DM 4139 per month).

${ }^{29}$ For at least 20 years' service in the company. 
Figure 4 shows, by way of comparison, the gross earnings of an average earner who takes advantage of the early retirement option in the insurance industry.

The gross income that an employee in the insurance industry can obtain during early retirement is therefore about the same as he or she would obtain by taking a one-third partial pension. In the insurance industry, therefore, a partial pensioner who claims only a third of his old-age pension is therefore no better off than someone who takes early retirement instead. Even if the average earner ceases to work altogether during early retirement, his gross income will be at about the same level as someone who takes a partial pension of one half.

\section{Interim conclusions}

The familiar pathways to retirement provide both employees and employers with a certain amount of freedom within the legislative framework. The partial pension extends these options. However, it involves significantly higher transactions costs, along with uncertain financial impact. ${ }^{30}$ Furthermore, the major extent to which retirement pathways enabling earliest possible exit from the labour force are taken advantage of shows that, with labour market conditions as they are, full rather than phased withdrawal is the more common practice, and that the opportunities for prolonging the working period within the life course are highly unfavourable. To what extent changing demographic conditions, and the concomitant changes in the labour market situation are already a component of longer-term personnel planning, and the status enjoyed by both postponed and phased retirement (particularly through the partial pension scheme), is dealt with in the following.

\section{Future Options for Extending the Employment Phase during the Life Cycle and for Phased Retirement in the German Insurance Industry}

\subsection{The development of employment and personnel structure as important determinants for extending the employment phase in the life cycle}

The potential for extending the employment phase during the life cycle lies, as the hypothesis presented in Section 1 would suggest, above all in human capital or human potential that the workforce in a company possesses. It therefore makes sense to study personnel structure more closely. Following a short overview of total staffing levels, the personnel structure in the insurance companies is then examined in terms of age, qualification, gender and working hours. The following data is derived from two sources in particular: the social statistics on the insurance industry obtained by the agv (the employers' federation), and our own survey data. To compare this data with those for the economy as a whole, we also carried out a separate analysis of employment statistics provided by the Federal Labour Office.

\subsubsection{The development of employment}

The number of employees rose during the 1980s in almost all the insurance companies surveyed. However, the employment level in the insurance industry as a whole decli-

${ }^{30}$ People are hesitant at first in their acceptance of new regulations, and to that extent are averse to risks; see, for example, Kohli/Wolf 1989, 154. 
ned between 1975 and 1985. This was caused by advances in data processing, especially, which was introduced in most companies during that period and which greatly increased labour productivity. Since 1986, however, the entire sector has seen renewed increases in the number of employees.

The insurance industry has profited enormously from German unification. Since then, the number of employees in the insurance sector has risen substantially. ${ }^{31}$ The number of employees with permanent employment contracts has risen since 1989 from 211,100 to 259,000 (1992). Figure $5^{32}$ shows how employment levels have developed over the last 10 years. In 1992, about 665,100 people were employed in the insurance sector (including agents and self-employed insurance sales people).

Figure 5:

Development of employment in the insurance industry

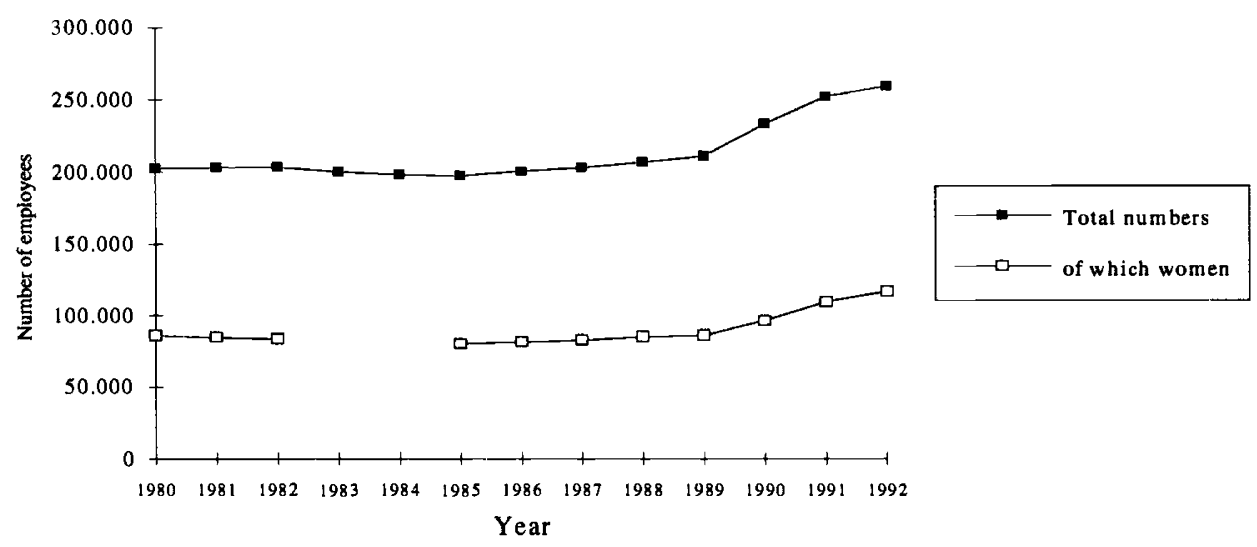

Nevertheless, some renowned insurance companies are now carrying out staff cuts, e.g. as part of restructuring measures. In the opinion of trade union representatives, early retirement is therefore an essential means for securing jobs for younger people. Of the companies surveyed, one reduced its staffing level in recent years due to reorganisation (mainly through natural fluctuation, but also with the help of an early retirement scheme), one is currently laying off employees, and yet another is planning to use a forthcoming restructuring phase to offer employees early retirement more than it has done to date.

31 This was also confirmed by the personnel directors we interviewed, with the exception of one insurance company that operates on a purely regional basis.

32 In 1992 there were 23,530,259 employees in Germany liable to compulsory social insurance contributions. The insurance sector is therefore only a small segment of the labour market. What is interesting, however, is that insurance companies has seen much greater growth in employment levels since 1950 than the economy as a whole. Employment rose almost 4-fold between 1950 and 1989, but by a factor of only 1.7 in the total economy (see agv 1990,62). 


\subsubsection{Personnel structure}

(a) Age

Before the potential for phased retirement can be assessed, it is necessary to study the age structure of the respective workforce. Particularly interesting is whether the age structure has change in recent years. See Figures 6-7 for age structures in the insurance industry. These are compared with the age structure of employees in the economy as a whole in Figures 8-933.

The proportion of under- 20 s has declined since the early $80 \mathrm{~s}$, in both the economy as a whole and the insurance industry, although to a greater extent in the former. The proportion of 55-60-year-olds has fallen from 6.6 to $5.2 \%$ in the insurance industry, but has risen in the national economy (from 6.9 to $8.1 \%$ ). The proportion of over- $60 \mathrm{~s}$ fell in the insurance industry over the same period to a greater extent than in the economy as a whole (from $2.1 \%$ to $0.9 \%$, against a slight fall in the national economy between 1980 and 1992 of 2.4 to $2.1 \%) .34$

The percentage of 20-30-year-olds increased over the last 10 years in most companies - one factor was that more persons with "A"-level equivalent school-leaving certificate were taken on for vocational training, another being the growing proportion of graduates in all insurance companies.

The average age of employees in the insurance industry remained constant over the last 10 years. The percentage of 40-50-year-olds, which is especially relevant for future development ${ }^{35}$, is now at $20.9 \%$, compared with $22.8 \%$ in $1982(20.6 \%$ in the overall economy, compared with $23.7 \%$ in 1980 ). However, the percentage of $50-55$-year-olds has risen slightly both in the national economy and in the insurance industry, an indicator that there will still be a substantial potential for early retirement in the years to come that companies are sure to make use of.

33 It should be pointed out that the age groups used in the insurance industry statistics differ somewhat from those in official statistics. The class limits for insurance companies are shifted upwards by one year, so that exact quantitative comparisons are not possible given the fact that higher numbers in marginal years could produce distortions.

34 According to Hoffmann $(1993,319)$, private service companies generally have an above-average proportion of over-50s compared to the economy as a whole.

35 Since this is the age group to which the increased age limits envisaged by the Pension Reform Act will first apply. 
Figure 6:

The age structure of the workforce in the insurance industry - 1982 and 1992

\begin{tabular}{|c|c|c|c|c|c|c|}
\hline \multirow{2}{*}{ Age } & \multicolumn{5}{|c|}{1982} & \multicolumn{3}{c|}{1992} \\
\cline { 2 - 7 } & Total & Men & Women & Total & Men & Women \\
\cline { 2 - 7 } & \multicolumn{5}{|c|}{ in \% } \\
\hline$<20$ & 6.9 & 5.0 & 9.6 & 4.4 & 3.2 & 6.1 \\
\hline $21-25$ & 13.3 & 9.9 & 18.2 & 14.5 & 11.2 & 18.7 \\
\hline $26-30$ & 14.3 & 13.0 & 16.4 & 16.9 & 15.6 & 18.8 \\
\hline $31-35$ & 13.9 & 15.0 & 12.1 & 14.4 & 15.0 & 13.6 \\
\hline $36-40$ & 12.1 & 13.6 & 9.9 & 13.0 & 13.8 & 12.0 \\
\hline $41-45$ & 13.4 & 14.5 & 11.9 & 11.6 & 12.4 & 10.5 \\
\hline $46-50$ & 9.4 & 10.0 & 8.6 & 9.3 & 10.3 & 8.0 \\
\hline $51-55$ & 8.0 & 8.7 & 6.9 & 9.8 & 10.8 & 8.5 \\
\hline $56-60$ & 6.6 & 7.1 & 5.8 & 5.2 & 6.3 & 3.6 \\
\hline$>60$ & 2.1 & 3.2 & 0.6 & 0.9 & 1.4 & 0.2 \\
\hline $\begin{array}{c}\text { Average age } \\
\text { in years }\end{array}$ & 36.8 & 38.4 & 34.5 & 36.8 & 38.2 & 34.9 \\
\hline
\end{tabular}

Source: Social Statistics for the Insurance Industry (agv 1993, 7)

Figure 7:

The age structure of empoyees in the insurance sector -1982 and 1992

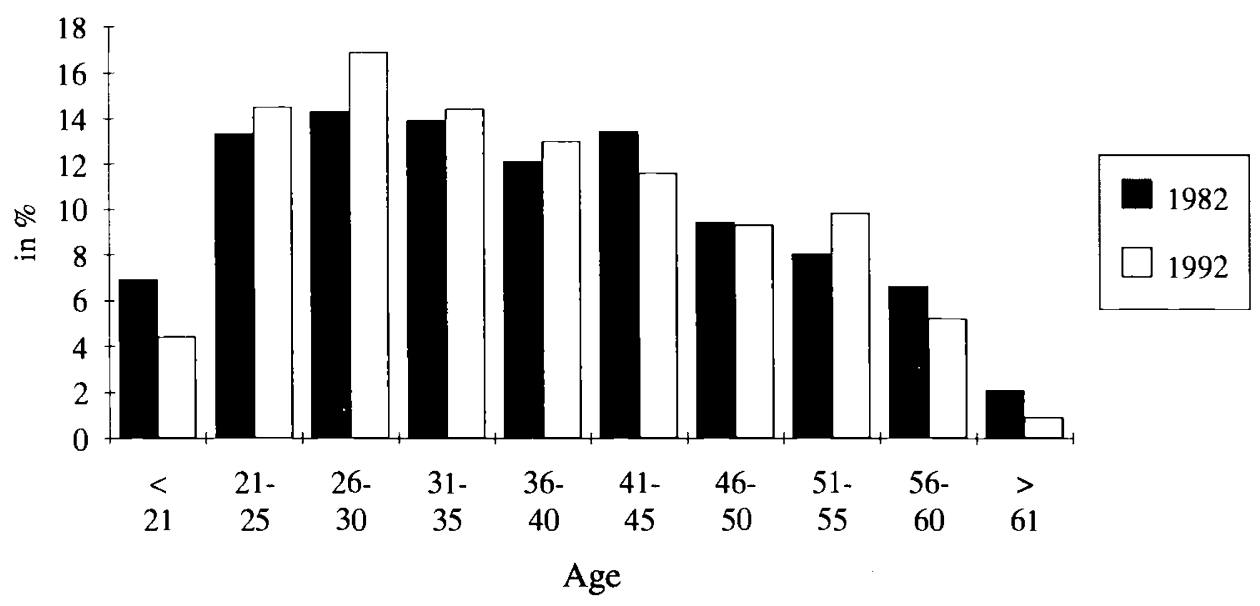


Figure 8: The age structure of employees liable to compulsory social insurance contributions - 1980 and 1992

\begin{tabular}{|c|c|c|c|c|c|c|}
\hline \multirow{2}{*}{ Age } & \multicolumn{5}{|c|}{1980} & \multicolumn{3}{c|}{1992} \\
\cline { 2 - 7 } & Total & Men & Women & Total & Men & Women \\
\cline { 2 - 7 } & \multicolumn{7}{|c|}{ in \% } \\
\hline$<20$ & 9.4 & 8.3 & 11.2 & 4.2 & 4.0 & 4.5 \\
\hline $20-24$ & 13.7 & 11.3 & 17.3 & 12.8 & 11.1 & 15.2 \\
\hline $25-29$ & 12.0 & 11.4 & 12.8 & 15.7 & 15.0 & 16.7 \\
\hline $30-34$ & 11.0 & 11.5 & 10.0 & 13.9 & 14.5 & 13.1 \\
\hline $35-39$ & 11.9 & 12.7 & 10.6 & 11.8 & 12.1 & 11.4 \\
\hline $40-44$ & 13.4 & 14.4 & 11.8 & 11.1 & 11.0 & 11.3 \\
\hline $45-49$ & 10.3 & 11.1 & 8.9 & 9.5 & 9.5 & 9.4 \\
\hline $50-54$ & 9.2 & 9.7 & 8.3 & 11.5 & 12.0 & 10.7 \\
\hline $55-59$ & 6.9 & 6.7 & 7.4 & 7.4 & 8.1 & 6.4 \\
\hline $60-64$ & 1.8 & 2.1 & 1.3 & 1.8 & 2.4 & 0.9 \\
\hline$>64$ & 0.6 & 0.6 & 0.5 & 0.3 & 0.3 & 0.3 \\
\hline
\end{tabular}

Source: Analysis of employment statistics

Figure 9:

The age structure of employees paying compulsory social insurance contributions -

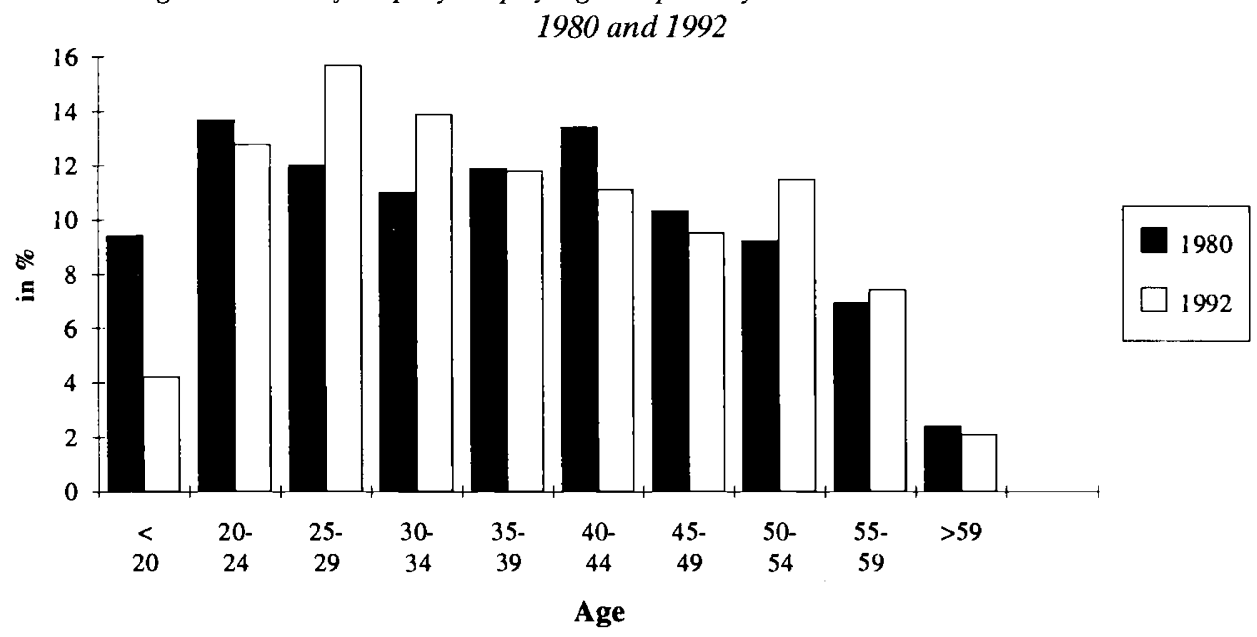


Seen in total, therefore, the age structure in the insurance companies has not undergone any major changes. It is more balanced than in the economy as a whole. For a direct comparison, see Figure 10.36

Figure 10:

Comparison of labour force age structures in the insurance industry and the economy as a whole, 1992

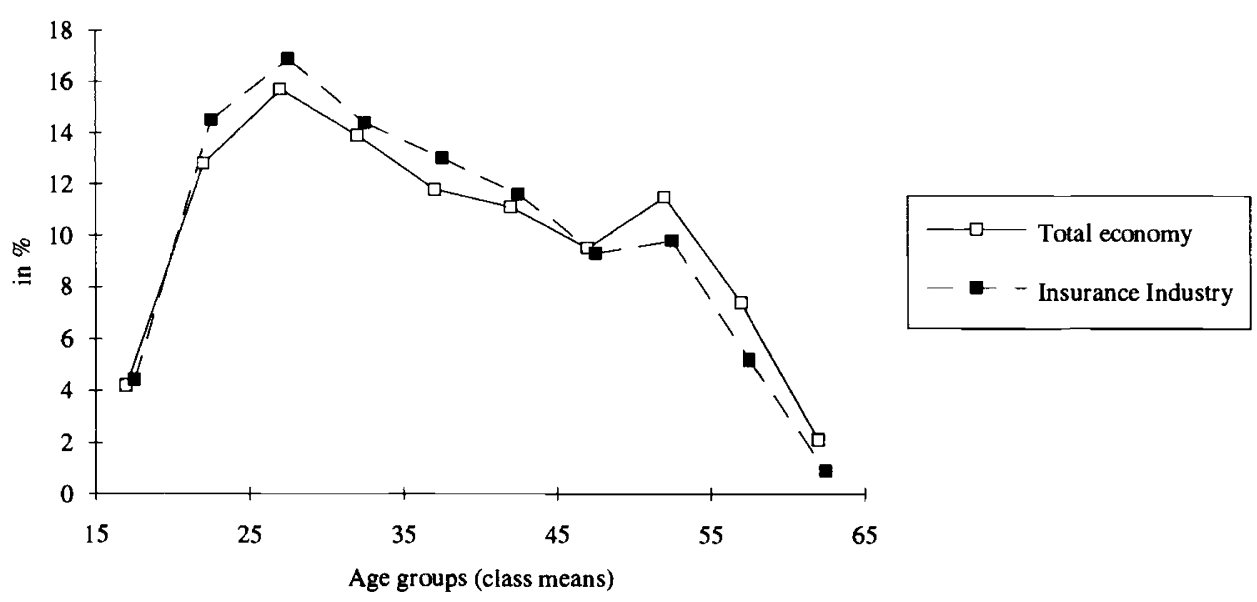

Source: Compilation of figures 7 and 9

The surveyed companies (to the extent that figures were available) show a similar personnel structure to that in the insurance industry as a whole. Reference was repeatedly made during the interviews to the low average age in the respective company.

\section{(b) Qualification}

Qualification has changed to a much greater degree than age structure has. The number of employees who have not completed any vocational training has fallen considerably, while the number of graduates rose between 1981 and 1992 from 8,300 to 17,300 (agv 1992 and 1993). Figure 11 provides details on this point.

${ }^{36}$ The figures are presented in the form of frequency polygons in order to demonstrate that, despite different class limits, distributions are quite different. 
Figure 11:

School education and vocational training of employees in the insurance industry in percent (former West German states)

\begin{tabular}{lcc} 
& 1982 & 1992 \\
\hline $\begin{array}{l}\text { Elementary and extended elemen- } \\
\text { tary school/ "O"-level without } \\
\text { vocational training }\end{array}$ & 15.9 & 8.7 \\
$\begin{array}{l}\text { Elementary and extended elemen- } \\
\text { tary school with vocational training } \\
\text { "A"-level equivalent without } \\
\text { vocational training }\end{array}$ & 70.5 & 63.1 \\
$\begin{array}{l}\text { "A"-level equivalent with } \\
\text { vocational training }\end{array}$ & 3.7 & 6.3 \\
$\begin{array}{l}\text { Higher technical college or } \\
\text { polytechnic }\end{array}$ & 3.7 & 11.5 \\
$\begin{array}{l}\text { University degree } \\
\text { Total }\end{array}$ & 2.1 & 3.0 \\
\hline
\end{tabular}

Source: agv 1993, 6

The proportion of qualified insurance employees with " $A$ "-level equivalent schoolleaving certificate has increased even more than the proportion of graduates. Change has been profound in this respect. During the 1980 s, insurance companies clearly followed a policy of employing mainly younger staff with high educational qualifications. The higher percentage of employees with the equivalent of "A"-levels, but without vocational training, may well result from there being more such school-leavers among the new trainee intake.

\section{(c) Gender}

Insurance companies today employ as many women as men (in fact, more women than men in the actual company offices). However, $93.6 \%$ of the external salaried representatives in 1992 were men (1982: 97.9\%); despite the increased proportion of women, this continues even today to be a purely male preserve in insurance companies.

The proportion of women among trainees has risen compared to the past. Some smaller insurance companies, with only 2 or so new trainees per year, employ only women, with the explanation that they "are simply better, firstly as regards qualification, but also in the interviews and assessment tests" (quote from an interview).

There are virtually no women at all (so far) in higher, and especially in executive positions (head of department and higher). However, the proportion of women is higher at group manager level than in higher executive positions, having risen here as well compared to the past (precise figures were not made available to us). 


\section{(d) Part-time employment}

The percentage of part-time employees increased over the ten-year period from 6.1 to $7 \%$, although in some of the companies surveyed the level is even higher (more than $10 \%$ ), thus corresponding to the proportion of part-time employment in the economy as a whole $(11.4 \%$ in 1992$) .37$

The agv data does not contain any reference to the proportion of women among parttime employees. Our own survey results show, however, that the proportion of women among part-time employees is probably $95 \%$ at least; nationally, the figure is $92.3 \%$ (according to employment statistics). Part-time work for men seems to have been even less desired or achieved in the insurance sector.

\section{Interim conclusions:}

In terms of workforce structure, the prerequisites for extending the working period in the insurance industry are favourable for the year 2010 and beyond, since those now aged 20-30 will then be 35-45 years old, already possess a high level of qualification and training, and are capable of retaining their potential for new and difficult tasks in the company when they are elderly if personnel development strategies are tailored to this end (life-long learning). Whether early retirement of a large proportion of the workforce was primarily a reaction to what for employers was a favourable recruitment situation on the labour market, or instead part of long-term personnel planning in response to demographic developments, is a question to which there is no straightforward answer. There is no doubt, however, that the policies applied so far, which aim at rejuvenation and higher skill profiles in the workforce, are an optimal basis for a strategy of extending the working period in the life cycle. Given the fact that the proportion of 50-55-year-olds in insurance companies will increase over the next few years, however, one can expect a continuation of the early retirement approach.

\subsection{Personnel policy in the surveyed insurance companies}

As described above, the human potential in the insurance industry demonstrates an exceptionally favourable structure. This situation needs to be made use of. An important criterion for implementing the relevant policies is how future demographic developments and their impact on the respective company are anticipated by personnel managers. We therefore chose a combination of two methods when conducting our study. Firstly, we examine the status quo with respect to certain aspects of personnel policy that are useful when determining the shape and form of an extended working period. Secondly, the assessment of future developments by the individuals interviewed is also included in the analysis, since they can function both as accelerators or as obstructers of extended working period strategies.

37 The actual rate of part-time employment is certain to be higher, since people in marginal employment (i.e. where pay is not subjected to social insurance contributions) are not included in employment statistics. According to the microcensus of May 1992, the rate of part-time employment in 1992 was $14.3 \%$; in the west German states this figure was $16 \%$, but only $7.2 \%$ in the new east German states. 


\subsubsection{Personnel recruitment}

Whether the urgent need to extend the working period in the life cycle is appreciated by people in these companies depends on the workforce structure as well as other factors, e.g. the recruitment opportunities on the external labour market. These aspects depend, in turn, on how attractive an employer the company is seen to be, something which those interviewed generally considered to be high in the insurance industry (mainly ascribed to pay levels and social benefits). ${ }^{38}$

All those interviewed agree that the qualifications and skills required have increased in recent years for virtually all positions. A certain ambivalence could be identified regarding the question of how future staff recruitment opportunities are assessed. On the one hand, all the companies are sure that they will be able to cover their personnel requirements in the long-term as well, but they also admit, on the other hand, that they are already having severe recruitment problems in some market segments. There is no shortage of graduates at present. In future, people with this level of education (especially those whose performance is only average) will have to accept the fact that they may be assigned normal office work as clerks.

Trainees are generally school-leavers with matriculation-level education. However, most of those interviewed stated that the quality of applicants was declining, and in some cases the quantity as well. School-leavers from secondary modern schools, especially, tended not to satisfy the requirements. This could well be an indicator for the onset of a scarcity of "new blood", although the statements made on this issue are not quite uniform; regional variations certainly exist.

There are already recruitment problems for positions that demand years of experience, e.g. specialists in the field of claims settlements. This at least is the situation as seen by larger and by smaller, specialised insurance companies.

In contrast, demand for traineeships for graduates is high, with as many as $200-300$ applications for each traineeship available. In the EDP field as well, it is easier today to find suitable applicants than it was a few years ago.

A number of office jobs can also be filled with commercially trained people from other sectors of the economy. Because insurance companies are also rationalising their operations, the supply of labour has even improved in some positions.

The people we interviewed do not expect any significant deterioration in their situation when asked to take a global view, since insurance companies are good employers as far as pay and social benefits are concerned. Furthermore, all the insurance companies place great value on their vocational and further training programmes, so that they hope to be able to cover their needs with their own employees. Internationally operating compa-

38 Continuous recruitment of "new blood" is easier for growing companies and companies with a favourable age structure (see Weber 1990, 274). It can be assumed that personnel marketing will become increasingly important in the future, not only with respect to new recruitment, but also for creating a positive attitude towards existing employees (high performance level and avoidance of labour turnover). On the subject of personnel marketing, see Scholz 1993, $600 \mathrm{ff}$, for example. 
nies also think that the Single Market may increase mobility and that the need for specialists in particular can be covered in this way. Ten years ago, hardly any staff was recruited from Great Britain, for example - today this is much easier to do.

Labour turnover is also relatively low (in the sector itself, but also among the companies surveyed). Those who leave are mostly younger staff members who have received better job offers from other companies. Interviewees complained about qualified staff being lost to the competition, but were also proud of their good position and reputation being confirmed in this way (good vocational and further training).

The early stages of mid-term planning can indeed be identified in this area: for example, almost all companies offer further employment during term holidays or on a part-time basis to ex-trainees who go on to university after their vocational training, in most cases committing them, in return for higher pay, to remain with the company for a specified number of years after completing their degrees. Companies are also trying to fill vacant managerial positions from their own ranks, which in turn requires personnel development measures for those in question (see Section 3.2.5 on this point).

On the whole, therefore, those interviewed do not anticipate any major problems on the recruitment front in the future, since the companies concerned have good staff and can assert themselves as attractive employers on the external market as well.

\subsubsection{Women}

Women often want to withdraw from employment (at least temporarily) when they have children. All the companies we surveyed grant $3^{1 / 2}$ years' maternity leave under the industry-wide collective bargaining agreement. Contact is usually maintained with these women during their absence; they can participate in further training, stand in for people on vacation, etc.

However, the people we interviewed rejected the idea of general programmes aimed at promoting women or assisting them when re-entering the labour force, and preferred individual solutions instead. Women often re-enter employment via part-time work once maternity leave is over.

Some companies complain in general terms about the lack of career orientation among their women employees. Others see this aspect in a more differentiated way. Wellqualified women, for example, took less maternity leave than provided for by law, and then come back to work full time.

Companies like these are trying to grant equal opportunities to women, with some impact already being achieved. Women are also present at group manager level in the companies we surveyed, and in some cases at department manager level.

Further increases in the employment participation rate of women is certainly feasible. Preference is generally given to the employment of younger women rather than keeping older employees on the payroll. Less recent empirical data indicate the same trend (see Wagner 1990). 


\subsubsection{Part-time employment}

The rate of part-time employment in most of the companies surveyed has risen in the course of time. Part-time employment, as already mentioned, is carried out almost exclusively by women. Women with children, especially, like working part time very much. As a rule, companies at least examine whether or not it is possible to switch from a full-time job to part-time employment, and in most cases it is. However, it is usually more difficult when the person concerned wants to work full time again after a number of years. If this involves reorganisation of the job or the responsibilities associated with it, what will often happen is that the woman has to change to a different job or department.

The overwhelming majority of those we interviewed believe that very many jobs could be shared, although some companies have doubts that jobs involving customer contact can be shared (the objective is that customers deal with the same person). The general opinion is that part-time employment in management positions is problematic. There are virtually no part-time executive positions, but sometimes at group manager level or among specialists. The reasons given do vary somewhat, however. In particular, the workload is considered too great for one person to cope with on a part-time basis. A second person has to be found to supplement the first, and must have the right skills (and leadership style). In the case of part-time work done by elderly employees, there is also the problem of finding a successor. If the successor is already there, the question remains as to how long he or she will be satisfied with the part-time position, i.e. the withdrawal phase has to be relatively short.

Another reason often given for why part-time employment is difficult to reconcile with managerial posts relates to how people in lower positions view their bosses. People still tend to adhere to old-fashioned leadership styles, and have difficulty accepting that their senior manager works less hours than they do.

What is interesting in this context is that personnel departments are giving more and more thought to the idea of part-time employment in higher positions. It is quite apparent, however, that a great deal of work still has to be done before employees will accept it as normal. In some cases, offering part-time employment in the form of special assignments is seen as one solution.

\section{Models offered:}

The standard working week is 38 hours. Below this limit, almost any number of hours can be worked. Companies tend to be very flexible in this regard, some offering several models that employees can choose from.

In most cases, however, working hours are designed to meet the specific needs of individuals, with a considerable amount of scope being given: one employee may work 4 hours a day, while the next works 2 days in one week, 3 days the next; another may work on a "one week on, one week off" basis; standing in for people on holiday (usually temporary employment contracts); job sharing, or teleworking. The tendency is to move away from a 4 hours per day system, because this is more difficult for the employees concerned to organise than more concentrated working hours. The main problems mentioned are the long distances to w urk or the time needed to get to work, and the organisation of child care. 
Companies with a shortage of space are tending more and more to seek two employees who will share one workplace.

Part-time employment is one area where employees generally have to take the initiative themselves, although companies will usually be responsive to wishes expressed.

Companies confirmed that most men do not want to work part time. When they do wish to do so, they often come under pressure to explain their reasons. Younger men only work part time when they are trying to take their doctor's degree or when they become fathers and their wives earn more than they do. The amount of pay continues to be the crucial factor when division of labour within the family is at issue.

Older men reduce their working hours earlier on in the life course when this is necessary for reasons of health, but otherwise they prefer to withdraw from employment early and abruptly.

Another problem is seen in the fact that part-time employment demands a greater sense of responsibility from all members of a team, regardless of level, and that employees realise that the group's performance is what matters. This is expected more of younger people, since they were brought up and trained in a different way to their elders.

\subsubsection{Flexibilisation of working hours, extending the working period}

The companies in the survey generally have arrangements for flexible working hours, with or without clock cards. There is a certain amount of variation regarding the extent to which hours can be transferred or saved up. The important point here, however, is that flexible working hours are the first step towards a more flexible design of working time, and that employees themselves can determine not only the number of hours to be worked, but also when they are worked.

One company is carrying out a project relating to flexible shaping of working hours. The aim is to ascertain to what extent employees want more flexible working time, what type of arrangements they prefer, and how these can be translated into actual practice. Interest in a more flexible design of the working period in the life cycle as a whole is thought to be very great. Younger (also male) employees, especially, show considerable interest in the idea. Obstacles are encountered, however, when it comes to specific details, for example if an employee wants to take a sabbatical and works out how many years he has to work 2 hours overtime in order to compensate..$^{39}$

Senior executives are not bound to a 38-hour week, but organise their work as they see fit. They normally work longer hours and at different times than normal employees.

Senior management already have flexible working hours in many cases. Some companies expect further developments of working time arrangements for all employees. Making working hours more flexible will also mean, in contrast to previous tendencies, that the

${ }^{39}$ This also corresponds with other research findings on phased retirement; see Bäcker/Naegele 1993, 69f for a summary view. 
working week can exceed 38 hours. However, the trade unions are resisting any attempts to raise the maximum number of hours per week. ${ }^{40}$

Personnel managers have pointed out that greater flexibility of working hours also involves more responsibility on the part of employee than has been common up to now. The conclusion this leads to is that more flexible design of working time arrangements can be implemented more easily where staff is higher qualified and where flat hierarchies and lean organisation exist.

\subsubsection{Personnel development}

"Personnel development should try to eliminate deficits in the know-how and skills of staff members, to fulfil their personal development objectives and to institutionalise lifelong learning" (Drumm 1992, 280). In the following, the main focus of analysis with respect to personnel development is further and continuing training, since this is considered to be fundamental to successful personnel development.

Insurance companies have already invested considerable sums in the field of further training. The unanimous opinion of all those we talked to, however, was that more will have to be done in future. The severe competitive pressure faced by insurance companies is the main reason given, not demographic developments. In general, further training is assigned considerable importance, and is a key element in personnel development strategies (as defined above). The range of further training on offer is correspondingly large.

Although the approach taken will vary from one company to the next, depending on the specific products and market position, the basic principles remain the same. Further training focuses primarily on themes which have a bearing on the specific industry (i.e. jobrelated and skill-related themes). This is shown by the fact that registration for courses is normally done through the senior manager, who can therefore channel the wishes expressed by those under him. Most companies do not have a pre-defined budget, but determine needs and then costs. The cost-effectiveness of training measures will tend to receive more attention in future, however. The range of courses has been reduced somewhat in some companies, the intention being to base them more on individual requirements and oriented more to demand on the part of employees. ${ }^{41}$. Testing the effectiveness of further training activities has typically been done using questionnaires and assessment forms to be filled out by participants. However, interviewees consider attempts by competitors to recruit one's own employees as a further indicator for the quality of vocational and further training. This shows the problems involved in assessing training measures, especially the actual benefits accruing to the company. Nevertheless, there are attempts to develop special controlling systems with respect to training, so that further training is geared more closely to actual needs. ${ }^{42}$

40 The new law governing working hours, which came into effect on 1.7.1994, extends considerably the scope wished for by employers. To what extent the collective bargaining parties will make use of the new opportunities for flexibilisation created by the law remains to be seen. For a discussion of the new law on working hours, see Anzinger 1994.

41 Thus, the intention here is to strengthen individual initiative on the part of employees.

42 See Scholz 1993, 672 ff, for example, on the objectives, tasks and methods of controlling systems in the field of education and training. 
All those we interviewed emphasised the importance of customer orientation. Recent years have seen increased efforts in this area. Interrelationships exist here with changing organisation structures and skill profiles. ${ }^{43}$ Employees must develop their communication skills and have a broader range of knowledge. The usual objective is to minimise the number of different departments that a customer may have to approach, i.e. better and more comprehensive service. Further training is mostly provided in-company, although the higher the position of participants in the company hierarchy, the greater the likelihood that further training courses are held externally.

Personnel development and career planning is normally provided for junior executives, whereby the attempt is made, through selection procedures and interviews aimed at determining potential, to give non-graduate staff members as well the chance to participate. Models for self-directed learning are deployed in some cases, so that employees learn at an early stage how to take over responsibility. There is usually an upper age limit for participants: "If someone aged $\mathbf{5 0}$ has not developed any management ambitions, it is unlikely that he will go to the top" (quoted from an interview).

Some companies are also endeavouring to establish similar programmes for people in careers below management level. However, such attempts are still at an early stage of development, similar to controlling systems for education and training.

The conditions for participation make no distinction between full-time and part-time workers, or according to age. In some companies, employees on maternity leave may also take part in seminars. However, part-time workers tend to participate to a lesser extent. The explanation offered is that such workers mostly have lower-qualified jobs.

One interesting issue in connection with further training and personnel development is the age at which employees are classed as being older. Interviewees tended to evade the question, but agreed on an age between 50 and 55. Employees in this age group are unlikely to receive any further training from the employer's side.

Statements regarding the willingness on the part of older workers to take part in further training varied considerably. In general, participation levels seem to decline with age and the number of years' service. Answers to this question can be grouped into three categories:

(1) Older workers participate less in further training because they expect to retire soon and have reached their final position within the company.

(2) Older workers have inhibitions, "they don't feel capable enough. They think the young ones learn certain things more quickly, or consider older colleagues to be stupid because they still can't do certain things at their age" (quoted from an interview).

(3) The basic willingness to take part in further training does not decline, since "they are just as involved as the younger ones when something really new is being dealt with" (quoted from an interview).

${ }^{43}$ Some companies go even further, stressing instead a customer group orientation when risk calculation permits this. 
Moreover, the desire for job-related further training seems to increase with age. Younger employees want to learn how to act and behave as managers. The older ones have no further need for such courses.

This demonstrates clearly that older employees can be motivated to continue learning, and in this way to perform work of a higher qualitative standard, provided that courses are tailored to the target group in question.

We also enquired about the extent to which older workers resist new teclinologies, with specific reference to the introduction of computers. Responses were differentiated. Some companies obviously encountered major problems, with the introduction of computers being interpreted by interviewees as a possible reason why some employees applied for early retirement. Other companies came to the conclusion that older workers were more reticent at the outset and perhaps needed more time to become familiarised with computers, but that younger people also put up resistance.

\section{Interim conclusions:}

Considerable importance is attached in the insurance industry to vocational and further training, although participation rates decline radically from about the age of 50 onwards - a factor that at least some of the companies consider problematic. In other companies, this has been interpreted as a logical consequence of early retirement. If someone aged about 58 takes early retirement, there is little point in investing any further capital in that particular worker. This is compounded by the fact that promotion prospects are minimal for those aged 50 and more, with the result that declining willingness to participate in further training is just as rational as the company's own attitude. In order to counteract any deskilling in the ageing workforces of the future, it is necessary to base further training for older workers on their actual needs. Restructuring training in terms of both content and didactical approach would provide older employees with more motivation to participate than has been the case so far. Employers and employees alike would profit from such moves.

A positive approach could be that taken in one particular company in the survey that organised a seminar for older workers, at irregular intervals, in which participants were able to discuss with others the problems associated with ageing. Reservations were expressed at the outset that one was simply trying to push older workers into an "old people's corner". Participants have been very satisfied with the seminar so far, and willingness to take part has risen accordingly. The seminar focuses on questions related to ageing, and retirement above all, of course. Seen the other way round, these kind of seminars can also be taken to show that satisfying work is also possible for older people who want to and are able to continue working.

Older people can indeed be motivated to take part in further training. The conditions in insurance companies are very favourable, in that willingness to participate in further training and the capacity to learn are all the greater, the higher the original level of education and the more continuously employees have "learned" during their employment history (see Klauder 1993, 29). 
Companies must therefore rethink their approaches in this regard. The sooner and the more continuous this extension of qualification is implemented, the greater the benefits that can be derived for all concerned from extending the working period within the life cycle.

\subsubsection{Company pension schemes}

All the companies we surveyed have a company pension scheme; benefits for senior executives are usually better than those obtained by the rest of the workforce. There are substantial variations in the forms that company pension schemes actually take - just about every kind of insurance can be found, from direct insurance to integrated retirement provision. Almost all companies were compelled to reorganise their company pension schemes during the 1980s, or at least to reduce benefits, because they were "excessive" 44 in many cases. This situation was not intentional, and companies were not able to finance it.

\subsubsection{Pathways to retirement}

Interviewees emphasised that most employees wish to retire as early as possible, but that there are also cases where employees would like to continue working beyond the official retirement age of 65 . The latter represent a small minority, however. Which groups of employees withdraw particularly early from the workforce seems to vary considerable from one company to the next. Some interviewees stress that senior executives and specialists identify themselves with their work and are motivated accordingly to work longer. Others complain about the fact that specialists want to retire as early as possible because they are so sorely needed. The specific point in time at which an individual wishes to retire is complied with in the majority of cases. However, there are also cases where early retirement has to be postponed for a year because the employee is needed in the company.

\section{(a) Early retirement}

Early retirement enjoys widespread acceptance. The collective bargaining agreement on early retirement is taken advantage of by about $40 \%$ of those entitled to do so (information provided by agv). However, there is a high degree of spread. The percentage taking the early retirement option ranges from $25 \%$ in some companies to over $80 \%$ in others. ${ }^{45}$

Roughly the same proportion of eligible workers took advantage of the Early Retirement Act that used to be in force. There is some uncertainty as to whether or not the early retirement agreement will expire at the end of 1994. If the trade unions succeed in obtaining a further reduction in working hours, it is possible that the agreement will not be renewed. The trade unions have an interest in keeping early retirement, in that jobs are

44 In other words, employees often had a net income from the statutory pension insurance scheme and the company pension scheme which was close to or even above their last net pay (see Schmähl/Böhm 1994 on the development of company pension schemes).

45 The reason for this statistical spread, besides the different extent to which companies promoted early retirement (e.g. in connection with restructuring), is also to be seen in the size of the company and the number of employees of eligible age. The decision of a single employee will have a much greater statistical impact in small companies than in a large corporation. 
also being cut in the insurance industry, and early retirement is a means of protecting the jobs of younger employees. ${ }^{46}$ Insurance companies typically use the early retirement option to implement restructuring and reorganisation measures more easily. It is still not clear whether early retirement is taken to a greater extent by more qualified or by less qualified employees. This depends on the personnel structure in the respective company, an aspect that we were unfortunately unable to determine for all companies.

\section{(b) Other pathways}

Employees who do not take the early retirement option claim a statutory old age pension as early as possible ( 60 for women and the severely disabled, 63 for men). In exceptional cases, some employees will continue working until they reach the age of 65 , mostly because they are not entitled to a old age pension before that or because the old age pension is very low. Only in very rare cases do employees work beyond the age of 65 . However, pensioners are sometimes employed as gatekeepers, for example.

Pensioners from one company were asked whether they would like to work again, or if they were actually satisfied with their situation. Surprisingly enough, none of those interviewed wanted to return to work, although perhaps they would stand in for someone in an emergency. The company concluded from this that employees prefer to stop abruptly and have virtually no interest in phased retirement of any kind.

One company has provided (for the last 14 years) a scheme for phased retirement during the last year before the planned retirement date. This option is used by $90-95 \%$ of all those eligible. Working hours are reduced by $30 \%$ during the first 4 months, by $40 \%$ during the next 4 and by $50 \%$ during the last 4 months (with pay remaining constant). The scheme gives older employees a "smooth" transition to the post-employment phase, and provides the company with an opportunity to familiarise the successor step by step with his new job. This model circumvents the problems that are seen to exist when senior management works part time only (described above).

Yet another company recently offered one of its employees a three-year phased retirement period (without partial pension). The employee rejected the offer, despite the fact that, in financial terms, pay exceeded the actual work he would have to perform. The same company is now considering what an appropriate duration for the phased retirement period would be. The latter two examples show that, in addition to the financial benefits, another highly significant factor is the length of the transition period. There seems to be a preference for shorter transitional periods, which involve less uncertainty for employer and employee than longer such periods.

\section{(c) Partial pensions}

Partial pensions have been discussed at least in all the companies. Some have even dealt intensively with the subject; discussions were also held with the works council in

46 This runs contrary to our original assumption that insurance companies still have slightly rising personnel requirements. 
some cases. Interviewees evaluated partial pensions in very different ways, depending neither on information and experience, nor on the size and type of enterprise involved.

Statements on partial pensions refer to three different aspects. Firstly, the question whether phased retirement is a meaningful option. The second aspect is the evaluation of postponed retirement. The third level concerns internal problems that could be generated when implementing partial pensions, problems which relate either to the specific design of partial pension schemes or to company-specific features which would have to be taken into account.

Typical statements on the first aspect maintain that the partial pension is basically a good idea and a meaningful addition to the previous retirement options. For most interviewees, however, phased retirement in combination with a higher retirement age is not a feasible option at this point in time, since the current labour market situation is such that employees are welcome to retire early. Moreover, the dominant opinion was that people aged 65 have worked long enough and have earned their retirement.

A step-by-step transition to retirement is therefore assessed positively, but not an extension of the working period in the life cycle. The people we interviewed, however, see the gradual transition to retirement using the partial pension option as being linked in all cases to an extension of the working period, which necessarily reduces the chances of partial pensions being implemented. Some explicitly referred to employees clearly preferring early retirement, and that the benefit deductions on early retirement would not stop the general trend.

Companies have also problems with the specific design of partial pensions. A frequently heard opinion was that the minimum eligibility age for a partial pension should be reduced to 58. In other words, despite the undisputed advantages of phased retirement, the partial pension would only become a genuine alternative to early retirement if the age limit for first receiving such a pension were lowered to 58 .

This connects up with statements regarding the relative unattractiveness of partial pensions compared to early retirement due to the high salary levels and the supplementary earnings limits in the insurance industry. Employees taking early retirement receive an income of the same order as the income they would obtain under a partial pension scheme. Even employees who would be interested in phased retirement and who inform themselves accordingly, decide in favour of the early retirement option after all.

This confirms the findings of previous studies on phased retirement, namely that verbal acceptance of a gradual transition is very high, but that those concerned ultimately prefer the abrupt switch (which is well known and socially accepted); particularly when income is roughly the same without having to work as it would be on reduced hours.

The financial unattractiveness of the partial pension is also due in part to the fact that company pensions are not paid until a full pension is first paid. ${ }^{47}$

\footnotetext{
47 This is seen as a problem that can be solved, however, as shown by deliberations in the individual companies and the employers' federation.
} 
Very different answers were obtained in response to the question whether the regulation is too complicated. Opinions did not correlate clearly with the level of information possessed, i.e. there are well-informed subjects who think the regulation is workable, but also less informed people who share the same opinion. Conversely, some of the betterinformed but also some of the less informed interviewees find the regulation too complicated. Responses ranged from "it's generally too complicated" to "it's not complicated, because you develop a routine when you have a lot of cases - it's no different with other new regulations".

What is interesting is that the part-time employment aspect does not seem to create the problems, but rather the possible postponement of retirement beyond the age of 65 . Such cases are occasionally encountered, for example when the individual concerned joined the company so late that entitlement to a company pension does not accrue until the age of 66. Specific experts who wish to continue working are permitted to do so. In the majority of such cases, however, a consultancy agreement or a contract for services is preferred to a normal employment contract.

The interviewees usually pointed out that if an elderly employee came and asked to do part-time work under the new legal provisions, they would probably be able to organise it. They themselves had no particular interest in encouraging this, however. This corresponds with the procedure described regarding the general issue of part-time jobs.

Rejection of any extension of the working period beyond the age of 65 is closely related to the intense debates regarding the validity of the age limits in collective bargaining agreements (65) at which an employment contract ends automatically. This regulation was abolished by the 1992 Pension Reform Act. Employers now fear being flooded with employees who refuse to retire unless they receive a settlement from the company ${ }^{48}$, although this seems to have occurred in isolated cases only. In the meantime (July 1994), the old legal situation has largely been reinstated, so that employment contracts are "automatically" terminated on reaching the age of 65 .

None of the companies encourages employees to take the partial pension option, not even those that are well informed. In one company, this is due to the integrated retirement provision that is still awarded under the company pension scheme. The company pension can only be claimed when a full pension is received, thus rendering a partial pension unattractive. In two companies that are very well informed about the partial pension, criticism is levelled at the individual limits on supplementary income, which are claimed to complicate the matter and make it impossible for the company to control.

It therefore comes as no surprise, given the above assessments, that there has only been one case so far of an employee taking a partial pension. The woman in question had reduced her working hours by $50 \%$ for one year and drew a partial pension at the same time. The initiative to take a partial pension came from the woman herself, who subsequently claimed her full pension at the age of 65 . The partial pension option was also in

48 This explains the current discussion regarding a return to fixed age limits in employment contracts, the objective being to prevent such "pokering" over settlements (see Handelsblatt, 24.5.94, 1). 
the company's interest in this case, because the job was due to be cut anyway and the one year provided a good opportunity to phase it out.

\section{Conclusion and assessment:}

Both employers and employees continue to favour options that provide for retirement at as early an age as possible. Companies do not generally pressurise employees into taking early retirement, but given the labour market situation and forthcoming restructuring within the respective companies, early retirement tends to be welcomed. The trend here is to greater flexibility regarding the actual scheduling of retirement, with preference being given to in-company solutions rather than obligations to institute certain measures being imposed by the legislature. In particular, 65 seems to be the commonly accepted age at which the employment phase should finally end.

Thought is being given to possible alternatives. The employers' federation is currently considering the advantages of partial early retirement. One company is debating whether to introduce a combination of part-time employment and early awarding of the company pension. Such ideas are still very vague, however.

The absence of any implementation of the statutory partial pension option in insurance companies is the result of several different factors. Firstly, the labour market situation is so unfavourable at present that longer-term strategies are being thought about but not implemented in any form. Pressure to restructure and cut staff levels appears so predominant that the relevant decision-makers have to dedicate their efforts to these tasks first and foremost. This is at least an indicator for the validity of the acceptance theory. Secondly, the rejection of partial pensions is a result of its specific design. In particular, the partial pension option does not pay off at present, neither for employers nor for employees - for three reasons:

(1) The existing early retirement agreement is financially very attractive compared to a partial pension system. Associated with this:

(2) The supplementary income limits under the partial pension system are too low.

(3) The age limits for the earliest possible receipt of a partial pension are too high.

The other reason cited by interviewees, namely that the transition phases are too long, is refuted by any objective analysis, since the duration of the transitional phase under the partial pension regulation can be defined separately for each individual case. Greater acceptance of the partial pension could be achieved by providing better information to all those involved.

\section{Opportunities for extending the working period in the future}

All trends, whether technological, economic or demographic, indicate a necessity for more extensive further education and greater work flexibility (with respect to working hours and pay), as well as more independence on the part of employees (see Scholz 1993, 21). This also provides an opportunity to extend the working period. 


\subsection{Flexibilisation and individualisation of working life in general}

The greatest opportunity for setting up an extension of the working period with a gradual transition to retirement as a "normal" form of retirement is offered by general tendencies towards flexibilisation and individualisation of working life. ${ }^{49}$ This includes such options as "sliding into" working life, variable working hours during employment phases, breaks in employment and an extension of the working period - or a combination of these components.

If they are to be advantageous for all those concerned, new models for working time and working period need to be both economical and social. For enterprises, this means better adjustment of working hours to their needs, for employees it signifies more time sovereignty, i.e. elimination of extraneous control and creation of new degrees of freedom (see Marr 1993, 25ff). However, new working time models cannot be simply applied to existing task and job structures. The latter must be reorganised at the same time. In this respect, the opportunity for reorganisation is extremely favourable at the moment since the lean management ${ }^{50}$ debate has prompted discussion of new organisational structures of work and, in particular, flatter hierarchies. This results in new (extended) forms of participation as well as more responsibility for employees, who are increasingly in favour of such changes (see Then 1993, 62ff.). The participation opportunities or the freedom offered in shaping working hours may bring about greater work satisfaction and thus increases in productivity. ${ }^{51}$ Therefore, every enterprise should also utilise the individualisation potential within the scope of the entire working period (see Kick 1992,2). Complete individualisation, however, involves related, (progressively) rising coordination costs (see Marr 1993, 37). The possible economic advantages of innovative working time management make this an important personnel policy instrument.

In the opinion of the majority of personnel experts surveyed, working hours will become more flexible in the future, both in an upwards and a downwards direction. Up to now flexibility in insurance companies below the collectively agreed working time has been very high because, in principle, any number of hours below that figure could be worked. The argument put forward that not all jobs can be shared may still apply to currently prevailing work structures, although the latter will inevitably have to change in the course of the flexibilisation desired by companies. Here there is an opportunity for extending the working period over the life cycle: it is true that men today prefer an abrupt transition to retirement compared to part-time employment at the end of their working life (see Bäcker/Naegele 1992,7). ${ }^{52}$ However, they will not have any status problems with part-time work at the end of their working life if they have had variable working hours during their

49 The primary aim of flexibilisation is to improve the company's performance whereas individualisation is intended to take the wishes of the staff into account (see Scholz 1993, 38). Long-term successful flexibilisation thus creates a simultaneously offered individualisation and vice versa..

50 See, for example, Scholz 1994 or Deppe 1993 in this context.

51 In extreme cases, wages completely independent of tinie might even be conceivable where the employees are paid for performing their task, no matter whether they complete it in 30 hours or 50 hours per week.

52 Whereas women primarily want part-time work so as to be able to combine occupation and family, the decisive reasons for men to work part-time, even today, are predominantly related to education or leisure time (see Schule-Brockhoff 1993, 9). 
working period and if they obtain an equally high income as prior to the reduction in working hours through, for example, a time savings account.

\subsection{Rising labour force participation rate of women}

The high proportion of well-trained women among employees in the insurance sector indicates that women are already very important for insurance companies. Although they have hardly managed to reach the executive level up to now, there are today, in contrast to the past, several women in management positions. The people we questioned stated that some improvements have taken place in this connection in recent years and it is expected that this development will continue in the future. The high rates of part-time work, which are in most cases due to women returning after a "baby break", shows that the insurance companies need women as employees. Women as superiors may become forerunners in the question concerning flexible working hours or part-time work among management staff as well. ${ }^{53}$ Then the gradual transition would no longer be tainted with the stigma of being shunted off or deskilled.

\subsection{Personnel development}

Further training today is quite well developed in all insurance companies. It has been even more tailored to "job-relevant" skills in recent years. In the future, however, it will be necessary to further extend the existing approaches to individualisation of personnel development. In particular, training concepts must be offered for all age groups. If it becomes evident that the final position in the company is not reached at the age of 45 or 50 , then further training is worthwhile, even at this age, for both employer and employees. Training concepts designed for all age groups are oriented to a non-uniform participant structure with the help of differentiation and flexibilisation. It would also be necessary to examine whether the modification of normal biographies also supports the possibility of working up "life-phase-oriented" concepts of further training and personnel development that encompass breaks in working life as well as training phases during these periods (see also the VW model in this context).

Special attention must be given to those between 40 and 50 years of age today, with whom a start must be made with further training that is suitable for their age group since they will be the first for whom the planned raising of the deduction-free age limits in the statutory pension insurance scheme will apply in full.

\section{Conclusions and prospects}

Final evaluation focuses on two separate aspects, corresponding to the organisation of the study. The first issue concerns the chances of implementing the partial pension, while the second has to do with long-term personnel planning and the influence of demographic changes on personnel policies.

53 The "normal employment relationship" with the rigid sequence of training - (full-time) employment - retirement has, as a rule, not applied to women up to now. 
Extending the working period in the insurance industry is not a viable proposition at present, despite the fact that structural conditions within the sector seem well suited. This cannot be explained purely in terms of attitudes on the part of personnel managers. The state itself must do more than simply redefine the legal framework (as is the case with the partial pension) and hope that this will lead to a rapid change of attitude among employers and employees, and that employees will remain in employment for longer again. Even if there were a basic willingness to do so, this is still counteracted, at least in the short to medium term, by the difficult labour market situation. On the other hand, it is conceivable that the demand for partial pensions will increase when entrance to retirement before the normal age limit is penalised with deductions. A preferred option can indeed lose its attractiveness for many of those affected if the right financial incentives are provided - and vice versa. ${ }^{54}$

Consideration must be also be given to possible changes in the conditions for obtaining a disability pension, to ensure that the use of partial retirement pensions are not cancelled out by an increase in disability pension claims.

Nevertheless, a general extension of the working period for all sections of the labour force is probably neither desirable nor feasible. Any full analysis must also take account of workers' preferences, their state of health, and the specific features of different fields of work or different workplaces.

We see few opportunities in the short term for implementing an extension of the working period; in the medium term, the state and private enterprise will have to coordinate their efforts - companies must develop personnel development plans that are also linked to flexibilisation aspects. This seems to be quite a realistic approach, since some of the personnel managers interviewed consider greater flexibilisation and individualisation of working time to be both desirable and inevitable. The insurance industry is well equipped to meet the demographic challenges that exist. Daily pressures leave little room for tackling strategic issues, however, and these challenges were of secondary priority for those we interviewed. Simply recognising the problems does not suffice, therefore. There must also be adequate problem-solving capacity and pressure to solve these problems. The acceptance theory suggests that it would make sense to assign the task of strategy development to a person with the right training and experience. 55 This employee can function as a catalyst both for the other members of the personnel department and for the workforce in general. This would lead to less resistance during the actual implementation phase. When more people, including those in younger generations, actually shape their working hours and work phases during the life course in a more flexible way, then having more scope regarding the type and the schedule of withdrawal from working life will also become widely accepted and taken advantage of according to personal needs and capacities.

54 Hoffmann $(1993,325)$ has pointed out, however, that the volume of cash assets in Germany is currently DM 3,500 billion, and that DM 100 billion are passed on by inheritance each year. In her estimation, this money will be used increasingly as a means of financing retirement. For many people, incentives for extending the working period in the life cycle based on "making ends meet" would simply not function.

55 See Weber 1990 as well on this point. 
New issues were raised in the course of the study, and some of the original questions could not be dealt with fully in the short period available. Important research tasks for the future involve two closely interrelated levels:

(1) The financial consequences for companies and employees must be made more transparent when developing and implementing new models for personnel development and the shaping of employment during the life course. A full cost-benefit analysis must take the changing conditions within macroeconomic, demographic and societal frameworks into account.

(2) With regard to demographic developments and the personnel structure within enterprises, there is a need to study the effects that an ageing workforce, combined with changing working conditions, will have on the working climate and on other important aspects of company microcosms. Such research work should develop the research issues that already exist within organisational demography. Combining the results of this reseach with the findings from (1) will enable the further development of demographically oriented personnel planning. 


\section{REFERENCES}

AGV (1990) Arbeitgeberverband der Versicherungsunternehmen in Deutschland: Tätigkeitsbericht 1985/1990, Munich.

AGV (1992) Arbeitgeberverband der Versicherungsunternehmen in Deutschland (Hg.): Sozialstatistische Daten der Versicherungswirtschaft 1991, Munich.

AGV (1993) Arbeitgeberverband der Versicherungsunternehmen in Deutschland (Hg.): Sozialstatistische Daten der Versicherungswirtschaft 1992, Munich.

ANZINGER (1994): Anzinger, Rudolf: “Arbeitszeitgesetz - Erfolgreich zum Abschluß gebracht”, in: Bundesarbeitsblatt 6/1994, pp. 5-9.

BÄCKER/NAEGELE (1989) Bäcker, Gerhard / Naegele, Gerhard: Wann und wie das Arbeitsleben beenden?, Cologne.

BÄCKER/NAEGELE (1992) Bäcker, Gerhard / Naegele, Gerhard: “"Heiß geliebt - aber dennoch verschmäht" - Der gleitende Übergang in den Ruhestand in Theorie und Praxis - Ergebnisse eines Forschungsprojektes", in: Zeitschrift für Sozialreform 9, pp. 504-519.

BÄCKER/NAEGELE (1993) Bäcker, Gerhard / Naegele, Gerhard: Alternde Gesellschaft und Erwerbstätigkeit - Modelle zum Übergang vom Erwerbsleben in den Ruhestand, Cologne.

BULLINGER ET AL. (1993) Bullinger, Hans-Jörg/ Volkholz, Volker/ Betzl, Konrad/ Köchling, Annegret/ Risch, Wolfram (Hg.): Alter und Erwerbsarbeit der Zukunft, Berlin u.a.

BUTTLER/TESSARING (1993) Buttler, Friedrich/ Tessaring, Manfred: "Humankapital als Standortfaktor - Argumente zur Bildungsdiskussion aus arbeitsmarktpolitischer Sicht", in: Mitteilungen aus der Arbeitsmarkt- und Berufsforschung No. 4, pp. 467-476.

CONRADI/JACOBS/SCHMÄHL (1987) Conradi, Hartmut / Jacobs, Klaus / Schmähl, Winfried (1987) "Vorzeitiger Rentenbezug in der Bundesrepublik Deutschland", in: Sozialer Fortschritt 8/1987, pp. 182-189.

CORNELSEN (1993) Cornelsen, Carsten: "Ergebnisse des Mikrozensus Mai 1992", in: Wirtschaft und Statistik No. 10, pp. 723-731.

DEPPE (1993) Deppe, Joachim: Personalwirtschaftliche Implikationen eines Lean-Managements, Arbeitspapier No. 20 des Instituts für Unternehmungsführung und Unternehmensforschung, RuhrUniversität Bochum.

DETERS/STAEHLE/STIRN (1989) Deters, Jürgen / Staehle, Wolfgang H. / Stirn, Ulrich: Die Praxis des gleitenden Übergangs in den Ruhestand - Geht eine sozialpolitische Idee in Rente?, Berlin 1989.

DEUTSCHE BUNDESBANK (1993) "Die Entwicklung des Arbeitsmarktes in Deutschland seit dem Ende der 80er Jahre", in: Monatsbericht der deutschen Bundesbank 8, pp. 55-65.

MEINHARDT/ZWIENER (1988) Meinhardt, Volker / Zwiener, Rudolf: "Vorruhestandsregelung sollte verlängert werden", in DIW-Wochenbericht 4, pp. 41-49.

DOMSCH (1989) Domsch, Michael: "Personal", in: Vahlens Kompendium der Betriebswirtschaftslehre, Vol. 1, pp. 501-603, Munich.

DRUMM (1989) Drumm, Hans-Jürgen (1989): "Vom Einheitskonzept zur Individualisierung: Neue Entwicklungen in der Personalwirtschaft"; in: Drumm, Hans-Jürgen (Hrsg): Individualisierung der Personalwirtschaft; pp. 1-13, Bern, Stuttgart.

DRUMM (1992) Drumm, Hans Jürgen: Personalwirtschaftslehre, Berlin u.a. ENQUETE-KOMMISSION DEMOGRAPHISCHER WANDEL (1994) Zwischenbericht,
Bundestagsdrucksache 12/7876 (14.6.1994). 
GAULKE (1992) Gaulke, Jürgen: Kursbuch Versicherung, Fischer Taschenbuch, Frankfurt/Main 1992.

GIARINI (1990) Giarini, Orio: "Introduction: the Opportunities of the Four Pillars' Strategy", in: The Geneva Papers of Risk and Insurance, No. 55, pp. 95-99.

GRÜTZ ET AL (1993) Grütz, Jens/ Lankes, Fidelis/ Tautz, Roland Roppel, Ullrich: "Modellrechnung zum Erwerbspersonenpotential und zur Arbeitsmarktbilanz bis zum Jahre 2030"; in: Deutsche Rentenversicherung 7/93, pp. 449-462.

HARTZ (1994) Hartz, Peter: Jeder Arbeitsplatz hat ein Gesicht - Die Volkswagenlösung, Frankfurt/M, New-York.

KAZMIERCZAK (1987) Kazmierzak, Ronald: Personalwirtschaft in privaten Versicherungsunternehmen, Berlin.

KICK/SCHERM (1993) Kick, Thomas/ Scherm, Ewald: "Individualisierung in der Personalentwicklung"; in: Zeitschrift für Personalforschung 1/93, pp. 35-49.

KICK (1992) Kick, Thomas: Individuelles Lebensarbeitszeitmanagement, Frankfurt u.a.

KLAUDER (1986) "Auswirkungen der zukünftigen Bevölkerungsentwicklung auf den Arbeitsmarkt - Analysen auf der Grundlage von Modellrechnungen des Instituts für Arbeitsmarkt- und Berufsforschung", in: Allgemeines Statistisches Archiv 1986, pp. 70-96.

KI.AUDER (1991) Klauder, Wolfgang: Ohne Fleiß kein Preis - die Arbeitswelt der Zukunft, ZürichOsnabrück.

KLAUDER (1993) Klauder, Wolfgang: "Ausreichend Mitarbeiter für die Tätigkeiten von morgen?", in: Bullinger, Hans-Jörg/ Volkholz, Volker/ Betzl, Konrad/ Köchling, Annegret/ Risch, Wolfram (Hg.): Alter und Erwerbsarbeit der Zukunft, Berlin u.a 1993, pp. 22-31.

KOHLI/WOLF (1989) Kohli, Martin/ Wolf, Jürgen: "Der Vorruhestand - Bilanz am Beispiel der chemischen Industrie", in: Die Mitbestimmung 3, pp. 152-156.

KOHLI ET AL (1991) Kohli, Martin u.a. (ed.): Time for Retirement - Comparative Studies of the Decreasing Age of Exit from the Labor Force, Cambridge u.a.

KOHLI (1993) Kohli, Martin: "Altersgrenzen als Manövriermasse? Das Verhältnis von Erwerbsleben und Ruhestand in einer alternden Gesellschaft", in: Strümpel, Burkhard / Dierkes, Meinhold (Hg.): Innovation und Beharrung in der Arbeitspolitik, Schäffer-Poeschel Verlag, Stuttgart 1993, pp. $177-208$.

HOFFMANN (1993) Hoffmann, Edeltraud: "Zur Beschäftigung älterer Arbeitnehmer in Westdeutschland - Qualitative und quantitative Aspekte", in: Mitteilungen aus der Arbeitsmarktund Berufsforschung No. 3, pp. 313-327.

HOFFMANN/KÜHLEWIND (1984) Hoffmann, Edeltraud /Kühlewind, Gerhard: "Arbeitsmarktund Kostenaspekte zur Vorruhestandsregelung - Datenmaterial und Modellrechnungen", in: Mitteilungen aus der Arbeitsmarkt- und Berufsforschung No. 2, pp. 135-157.

KRUSE/STEINJAHN (1988) Kruse, Jürgen / Steinjahn, Werner: Verlängerung der Lebensarbeitzeit und Flexibilisierung des Uberganges vom Erwerbsleben in den Ruhestand im Hinblick auf künftige Erfordernisse des Arbeitsmarktes und der Alterssicherung, Karlsruhe.

MARR (1989) Marr, Rainer: "Überlegungen zu einem Konzept einer "differentiellen Personalwirtschaft'"; in: Drumm, Hans-Jürgen (Hg.): Individualisierung der Personalwirtschaft; pp. 37-47; Bern, Stuttgart.

MARR (1993) Arbeitszeitmanagement: "Die Nutzung der Ressource "Zeit" zur Legitimation einer bislang vernachlässigten Managementaufgabe", in: Marr, Rainer (Hg.): Arbeitszeitmanagement, Berlin, pp. 13-38. 
MINSSEN (1993) Minssen, Heiner: "Lean production - Herausforderung für die Industriesoziologie", in: Arbeit 1/1993, pp. 36-52.

NIENHÜSER (1989) Nienhüser, Werner: Langfristige demographische Veränderungen und Personalstrategien - Ein Problemaufriß und erste Hypothesen, Schriften aus dem Arbeitskreis Betriebswirtschaftliche Verhaltensforschung, Universität-Gesamthochschule Paderborn.

NIENHÜSER (1991) Nienhüser, Werner: "Organisationale Demographie - Darstellung und Kritik eines Forschungsansatzes", in: Die Betriebswirtschaft 1991, pp. 763-780.

NIENHÜSER (1992): Nienhüser, Werner: "Wirkungsanalyse und Gestaltung betrieblicher Personalstrukturen - am Beispiel der Altersstruktur", in: Zeitschrift für Personalforschung 1/92, pp. 75-96.

PFEFFER (1985) Pfeffer, Jeffrey: "Organizational Demography: Implications for Management", in: California Management Review, Number 1, pp. 67-81.

RAJAN/ VAN EUPEN (1990) Rajan, Amin / van Eupen, Penny: The Fourth Pillar and the UK insurance industry, Etudes et Dossiers No. 145 by the Geneva Association, Geneva.

RAJAN/ VAN EUPEN (1991) Rajan, Amin / van Eupen, Penny: "Potentials for the Fourth Pillar in Japan, the Netherlands and the USA in insurance and other sectors", in: Etudes et Dossiers No. 161 by the Geneva Association, pp. 1-55.

REDAY-MULVEY (1991) Reday-Mulvey, Geneviève: "The potential for the Fourth Pillar in France in Insurance and other sectors", in: Etudes et Dossiers No. 161 by the Geneva Association, pp. 57114.

ROSENOW (1992a) Rosenow, Joachim: "Personalanpassung durch Verrentung - Zur Regulierungslogik der altersselektiven Externalisierungsstrategie in bundesdeutschen Unternehmen", in: Arbeit No. 2, pp. 144-165.

ROSENOW (1992b) "Die Altersgrenzenpolitik in den neuen Bundesländern: Trends und Regulationsmechanismen im Transformationsprozeß - Differenzen zur Entwicklung in den alten Bundesländern", in: Zeitschrift für Sozialreform 11-12, pp. 682-697.

ROSENOW/NASCHOLD (1993) Rosenow, Joachim/ Naschold, Frieder: Ältere Arbeitnehmer "Produktivitätspotential oder personalwirtschaftliche Dispositionsmasse?"; in: Sozialer Fortschritt 6-7, pp. 146-152.

SCHERM (1990) Scherm, Ewald (1990): Unternehmerische Arbeitsmarktforschung, Munich.

SCHMÄHL/CONRADI (1984) Schmähl, Winfried/ Conradi, Hartmut: "Der Kosten- und Beschäftigungseffekt von Vorruhestandsreglungen", in: Wirtschaftsdienst, Vol 64, pp. 126-131.

SCHMÄHL/BÖHM (1994) Schmähl, Winfried / Böhm, Stefan: Occupational pension schemes in the private and public sector in the Federal Republic of Germany - an overview, paper presented for the IRES Conference on "Supplementary Pensions: Actors, Issues and the Future", Paris, January 26-28, 1994.

SCHMÄHL (1988) Schmähl, Winfried (Hg.): Verkürzung oder Verlängerung der Erwerbsphase? - Zur Gestaltung des Übergangs vom Erwerbsleben in den Ruhestand in der Bundesrepublik Deutschland, Tübingen.

SCHMÄHL (1989) Schmähl, Winfried (ed.): Redefining the Process of Retirement - An International Perspective, Berlin u.a.

SCHMÄHL (1992a) Schmähl, Winfried: "Chancing the Retirement Age in Germany", in: The Geneva Papers on Risk and Insurance, No.62, pp. 81-104. 
SCHMÄHL (1992b) Schmähl, Winfried: "Zur zukünftigen Entwicklung des Rentenalters in Deutschland - Von rechtlichen Regelungen zu ökonomischen Wirkungen. Hypothesen und Aufgaben", in: Förster, Wolfgang/ Rößler, Norbert: Betriebliche Altersversorgung in der Diskussion zwischen Praxis und Wissenschaft, Cologne 1992, pp. 1-18.

SCHMÄHL (1993) "The 1992 Reform of Public Pensions in Germany: Main Elements and some Effects", in: Journal of European Social Policy, Vol 3, No. 1, pp. 39-51.

SCHOLZ (1993) Scholz, Christian: Personalmanagement, ${ }^{3}$ Munich.

SCHOLZ: (1994) Scholz, Christian: "Lean Management", in: WiSt No. 4/94, pp. 180-186.

SCHUH ET AL. (1993) Schuh, Sebastian/ Schultes-Jaskolla, Gabriele/ Stitzel, Michael: "Alternative Arbeitszeitstrukturen", in: Marr, Rainer (Hg.): Arbeitszeitmanagement, Berlin, pp. 115-159.

SCHULZ (1993) Schulz, Erika: "Bevölkerungsentwicklung in Deutschland bis zum Jahr 2010 mit Ausblick auf 2040", in: DIW-Wochenbericht 29, pp. 393-404.

SCHULZE BUSCHOFF (1994) Schulze Buschoff, Karin: Arbeitszeitpräferenzen - Basisdaten für eine bedürfnisgerechte Arbeitszeitgestaltung, Arbeitspapier, pp. 94-102 der Arbeitsgruppe Sozialberichterstattung am WZB, Berlin.

STITZEL (1987) Stitzel, Michael: Der gleitende Übergang in den Ruhestand - Interdisziplinäre Analyse einer alternativen Pensionierungsform, Frankfurt/M, New-York.

TAYLOR/WALKER (1993) Taylor, Philip /Walker, Alan: "Employers and older workers", in: Employment Gazette August 1993, pp. 371-378.

TERIET (1990) Teriet, Bernhard: "Die Teilzeitarbeit als Instrument des Arbeits- und Betriebszeitmanagements", in: Ackermann, Karl-Friedrich / Hofmann, Mathias (Hg.): Innovatives Arbeitszeitund Betriebszeitmanagement, Frankfurt/M u.a., pp. 105-114.

THEN (1993): Then, Manfred: "Die Evolution im System Arbeit - Zusammenhänge und Perspektiven für die Zukunft", in: Marr, Rainer (Hg.): Arbeitszeitmanagement, Berlin, pp. 59-75.

VIEBROK (1993): Viebrok, Holger: "Rentner auf Raten - Betriebliche Gestaltungsmöglichkeiten des Übergangs vom Erwerbsleben in den Ruhestand"; in: Angestelltenkammer Bremen/Mittelstädt, Armin (Hg.): Betriebliche Sozialpolitik, Hamburg.

WAGNER (1990) Wagner, Gert: "Bevölkerungsentwicklung und betrieblicher Personalbedarf aus volkswirtschaftlicher Sicht", in: Felderer, Bernhard (Hg.): Bevölkerung und Wirtschaft, Berlin, pp. 455-471.

WEBER (1990): Weber, Wolfgang: "Bevölkerungsentwicklung und Personalplanung"; in: Felderer, Bernhard (Hrsg): Bevölkerung und Wirtschaft; Berlin, pp. 273-285.

WOLF/KOHLI (1988): Wolf, Jürgen / Kohli, Martin: "Neue Altersgrenzen des Arbeitslebens Betriebliche Interessen und biographische Perspektiven", in: Rosenmayr, Leopold/ Kolland, Franz (Hg.): Arbeit-Freizeit-Lebenszeit, Opladen 1988, pp. 183-206. 